\title{
Os Efeitos da Migração Interpartidária na Conduta Parlamentar*
}

\author{
Celso Roma
}

\section{INTRODUÇÃO}

\begin{abstract}
migração interpartidária é um fenômeno recorrente na Câmara A dos Deputados desde o retorno à democracia. O número de parlamentares que trocam de partido se revela alto em todas as legislaturas. Em média, cerca de um terço dos mandatários abandona, pelo menos uma vez, a legenda pela qual se elegeu (Melo, 2000). Ao longo dos últimos 20 anos, mais de 700 deputados federais mudaram sua filiação. Alguns deles mudam de partido antes mesmo de tomar posse do seu mandato ou fazem isso várias vezes durante o exercício de suas atividades representativas (Melo, 2004). Há casos extremos de deputados que, em uma legislatura, migraram seis vezes ou mais. Essas ocorrências, em vez de diminuírem com o passar do tempo, ao contrário, agravaram-se. A 52a legislatura, relativa ao primeiro governo de Luiz Inácio Lula da Silva, registrou o pico de 195 migrantes e 345 movimentos
\end{abstract}

\footnotetext{
*Este artigo é uma versão daquele apresentado no 5ํㅡㄹ Encontro da Associação Brasileira de Ciência Política - ABCP, realizado em 2006. Sua elaboração baseou-se no terceiro capítulo da minha tese de doutorado, defendida na Universidade de São Paulo - USP, em 2005. Gostaria de registrar o apoio e o material que recebi de Scott W. Desposato e Keith T. Poole. Agradeço os comentários e as críticas ao texto, de Fernando Limongi, Maria D’Alva Kinzo, Leandro Piquet Carneiro, Carlos Pereira, Fabiano Santos, Lucio Rennó e Marcus Ianoni. O parecerista anônimo fez observações que ajudaram a revisar o artigo. A Fundação de Amparo à Pesquisa do Estado de São Paulo - FAPESP financiou o desenvolvimento desta pesquisa.
}

DADOS - Revista de Ciências Sociais, Rio de Janeiro, Vol. 50, no2, 2007, pp. 351 a 392. 
entre as legendas, correspondendo a um acréscimo substancial em relação aos números registrados na legislatura anterior ${ }^{1}$.

A magnitude desse fenômeno pode ser explicada por fatores de natureza estrutural e conjuntural. A legislação atual permite aos políticos mudarem de partido sempre que julguem conveniente, diferenciando-se do regulamento que vigorou durante o sistema bipartidário imposto pelo autoritarismo. Se as leis previssem a perda do mandato como forma de punir a deserção, os parlamentares certamente manter-se-iam fiéis à sua legenda. Ademais, o sistema partidário brasileiro caracteriza-se, entre outros atributos, pelo grande número de legendas que solicita nada mais do que a formalidade para a afiliação em seus quadros (ver Lima Junior, 1993; Nicolau, 1996; Mainwaring, 1999). Há muitas alternativas de filiação e poucas exigências a serem cumpridas, o que facilita o trânsito de deputados de um partido a outro. E, o mais importante, a deslealdade é resultado de um jogo de interesses entre os atores coletivos e individuais. As organizações partidárias ${ }^{2}$ incentivam o ingresso de políticos em seus quadros com o intuito de aumentar o tamanho de suas bancadas e, com isso, obter maior poder de barganha no Congresso Nacional, mais recursos do Fundo Partidário e mais tempo de exposição no horário de propaganda política. É por esse motivo que as mudanças de partido estão condicionadas pelo calendário eleitoral (Diniz, 2000). Por sua vez, os parlamentares migram visando aos benefícios de curto prazo que os ajudem a promover sua carreira e conseguir a reeleição (Desposato, 2006). Com a troca de partido, eles podem obter candidatura para a disputa de um cargo eletivo, ocupar postos no governo federal, receber apoio do presidente da República (Araújo, 2000), sobretudo quando a sua popularidade está em alta, ou participar das comissões e da Mesa Diretora (Melo, 2000). A movimentação interpartidária atende, deste modo, a interesses dos deputados e dos próprios partidos ${ }^{3}$.

A imprensa em geral divulga reportagens criticando as mudanças de partido que são totalizadas ao final de cada legislatura e as atribui corretamente ao oportunismo dos parlamentares. Os eleitores também parecem reprovar os representantes que migram durante o exercício do seu mandato. Comparados aos deputados fiéis, os infiéis têm chances menores de se reelegerem e, quando transitam entre partidos de diferentes blocos ideológicos, a sua probabilidade de reeleição é bem menor (Schmitt, 1999; Melo, 2004). Nos estados da federação onde a deslealdade partidária é acentuada, os eleitores tendem a punir os candida- 
tos a uma vaga para deputado federal, transferindo seus votos de um partido para outro e, dessa maneira, tornando menos previsível o re-

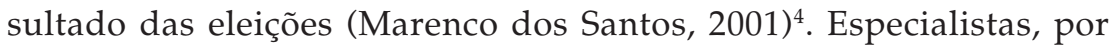
seu turno, condenam as trocas de partido porque elas alteram artificialmente a congruência entre os números de cadeiras e de votos conquistados pelos partidos e dificultam que os políticos estabeleçam reputação em uma sigla. Argumentam que, nas democracias, e em especial naquelas que adotam o sistema proporcional, a força dos partidos deve corresponder ao resultado que eles logram nas urnas. Apesar de reconhecerem que os eleitores votam em uma lista aberta de candidatos apresentadas pelas legendas, os críticos consideram as mudanças de filiação como um desrespeito à vontade dos eleitores.

Efetivamente, a deserção partidária pode ser observada em grande número, motivada pelos interesses particulares dos parlamentares, rejeitada pela opinião pública e criticada pelos estudiosos do assunto. Contudo, baseando-se apenas nessas constatações, não é possível considerá-la um problema em si para o sistema representativo. Para que esta alegação seja procedente, várias conjecturas necessitam ser comprovadas. Em primeiro lugar, parlamentares desertores deveriam estar malalocados no partido pelo qual assumiram o seu mandato e, em razão disso, comparados aos seus colegas leais, votariam mais vezes contra as orientações do seu líder e expressariam idéias divergentes da sua bancada. Em segundo lugar, deputados migrantes deveriam revelar um grau mais elevado de partidarismo na legenda de destino, fato que, se observado, constituiria forte indício de que as mudanças de filiação corrigiriam a ineficiência do recrutamento dos partidos, que selecionariam filiados sem afinidade com o seu programa. Em terceiro, a maioria dos deputados desertores deveria transitar entre partidos ideologicamente díspares, rescindindo o acordo estabelecido com os seus eleitores no qual eles se propuseram a defender determinada posição política. Enfim, infidelidade partidária deveria acarretar grave problema para o funcionamento da Câmara Baixa, tal como se teoriza, tomando-se como referência outros países. Essas suposições, porém, ainda não foram averiguadas porque a literatura focaliza a magnitude e as causas da migração partidária, e não as suas conseqüências para o processo legislativo.

Dialogando com os estudos anteriores, meus objetivos neste artigo consistem em: a) avaliar comparativamente o desempenho de deputados leais vis-à-vis desertores quanto ao compromisso deles de expressar 
idéias compatíveis com a agenda do partido ao qual estiveram filiados e de apoiá-la nas votações da Câmara; b) interpretar o sentido da movimentação de parlamentares entre os partidos, após classificar a ideologia das siglas de origem e de destino; c) observar a posição dos deputados migrantes no contínuo esquerda-centro-direita, antes e depois da troca de partido; e, por último, d) confrontar as características da infidelidade partidária nas câmaras baixas do Brasil e dos Estados Unidos.

O argumento a ser desenvolvido é o de que a infidelidade partidária na Câmara dos Deputados é menos prejudicial ao sistema representativo do que se estabelece por convenção. Parlamentares leais ou desertores acatam, no plenário, os encaminhamentos de voto do líder e expressam, nas sondagens, idéias compatíveis com a agenda do partido. Os dois grupos cumprem as obrigações assumidas com a sua legenda. Além disso, as mudanças de partido revelam-se consistentes do ponto de vista ideológico. Os migrantes escolhem, dentre as diversas alternativas de filiação, aquela com uma ideologia semelhante à do partido de origem e repetem, no partido de destino, seu ideário e seu modo de votar. Eles trocam de partido, mas, na prática, continuam marcando a mesma posição política. Somente uma pequena minoria transita entre os blocos ideológicos e muda o seu comportamento, desvirtuando a representação da preferência dos seus eleitores. O contexto de multipartidarismo e de contigüidade entre as legendas torna possível que os deputados se movam entre elas e, ao mesmo tempo, conservem a sua identidade. Esse cenário contrasta com aquele observado na Câmara dos Representantes norte-americana, cuja composição está concentrada em dois partidos polarizados no espectro ideológico. Seus parlamentares raramente migram, pois, ainda que as mudanças de legenda sejam consentidas pela legislação, a estrutura do sistema partidário as restringe, e quando eles se movimentam entre as siglas democrata e republicana criam necessariamente um problema para a representatividade dos seus eleitores.

\section{INFIDELIDADE E PARTIDARISMO NA CÂMARA DOS DEPUTADOS}

Esta seção examina o desempenho dos deputados leais e dos desertores no que se refere às iniciativas do seu partido para impor a sua agenda. Dois indicadores de partidarismo serão utilizados. O índice de coesão refere-se à afinidade de idéias que os parlamentares demonstram, em relação à sua bancada, ao se posicionarem a respeito dos temas que compõem determinada agenda. A enquete, por garantir a condição de anonimato aos participantes, permite aos parlamentares manifesta- 
rem-se sem condicionar suas respostas às expectativas dos seus eleitores ou dos seus correligionários. O índice de disciplina reporta-se aos votos dos deputados, no plenário da Câmara, em conformidade com os encaminhamentos dos líderes do seu partido. Os registros de votos nominais mostram como os parlamentares se relacionam com os seus líderes no processo de tomada de decisão. Considerados em conjunto, esses indicadores medem o grau de adesão dos deputados ao ideário e orientações da sua legenda ${ }^{5}$.

A Tabela 1 mostra o índice de coesão dos deputados por categoria de fidelidade partidária. Em todos os levantamentos, os valores obtidos por leais ou desertores ultrapassam 70 pontos em 100 . Comparando esses agrupamentos, podemos notar uma diferença que não ultrapassa oito pontos percentuais. A maior vantagem dos leais foi observada na última sondagem, de 1997. Em contraposição, nas de 1991 e 1995, os desertores alcançaram uma taxa um pouco mais elevada. Em outros anos, as taxas de unidade entre os grupos são bastante similares, e os desvios-padrão, por serem baixos, indicam que seus integrantes têm escores próximos à média. Os testes estatísticos comprovam tanto a igualdade das médias como a igualdade das variâncias dos indicadores de coesão dos deputados leais ou desertores.

A Tabela 2 avalia o índice de coesão dos deputados, aí agrupados de acordo com o número de legendas às quais estiveram filiados ao longo de suas carreiras. Essa informação, embora tenha sido anotada apenas na pesquisa de 1995, comprova que sequer há diferença entre os parlamentares que sempre foram fiéis a uma legenda e os que passaram por três ou mais legendas. O nível de unidade mostrou-se elevado até mesmo entre os parlamentares cuja trajetória partidária é muito irregular, marcada por três ou mais mudanças de filiação. Os estimadores que comparam médias e variâncias confirmam esses achados.

A Tabela 3 compara as taxas de coesão dos deputados migrantes na sigla à qual estavam filiados antes de se desligarem e as dos seus correligionários que permaneceram leais a ela, procurando encontrar diferenças dentro de cada partido. A única diferença em favor dos leais, superando os 15 pontos, pode ser encontrada nos pequenos partidos de esquerda - PPE. Os emigrantes do PSDB* e do PTB são um pouco mais coesos do que os demais membros da sua antiga bancada. No caso do

* Ver lista de siglas dos partidos políticos com os respectivos significados ao final do artigo. 


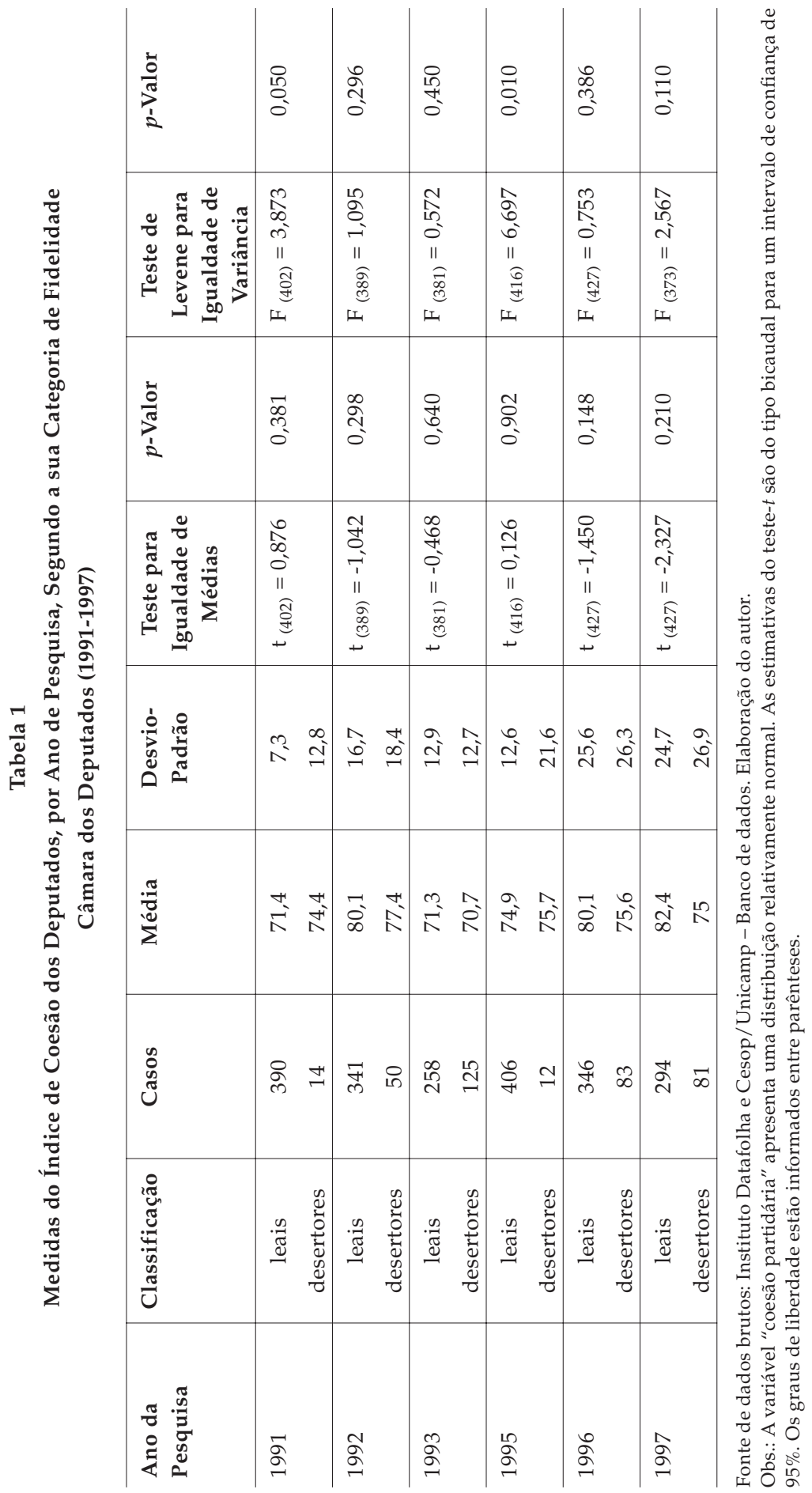


Os Efeitos da Migração Interpartidária na Conduta Parlamentar

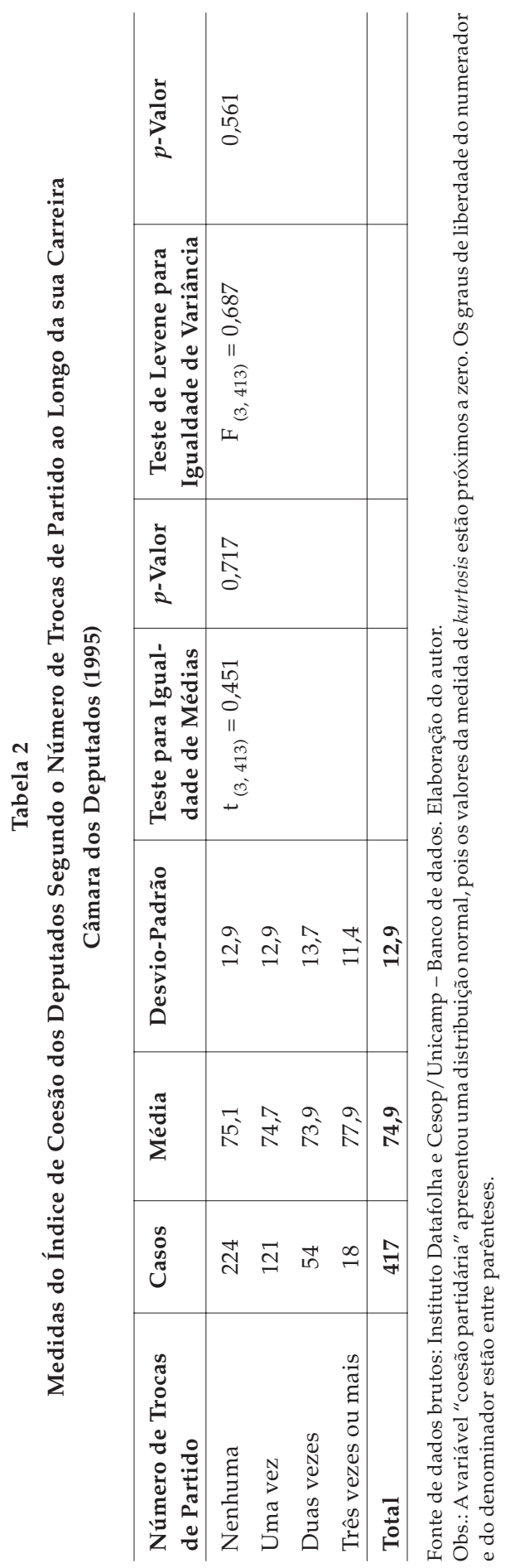




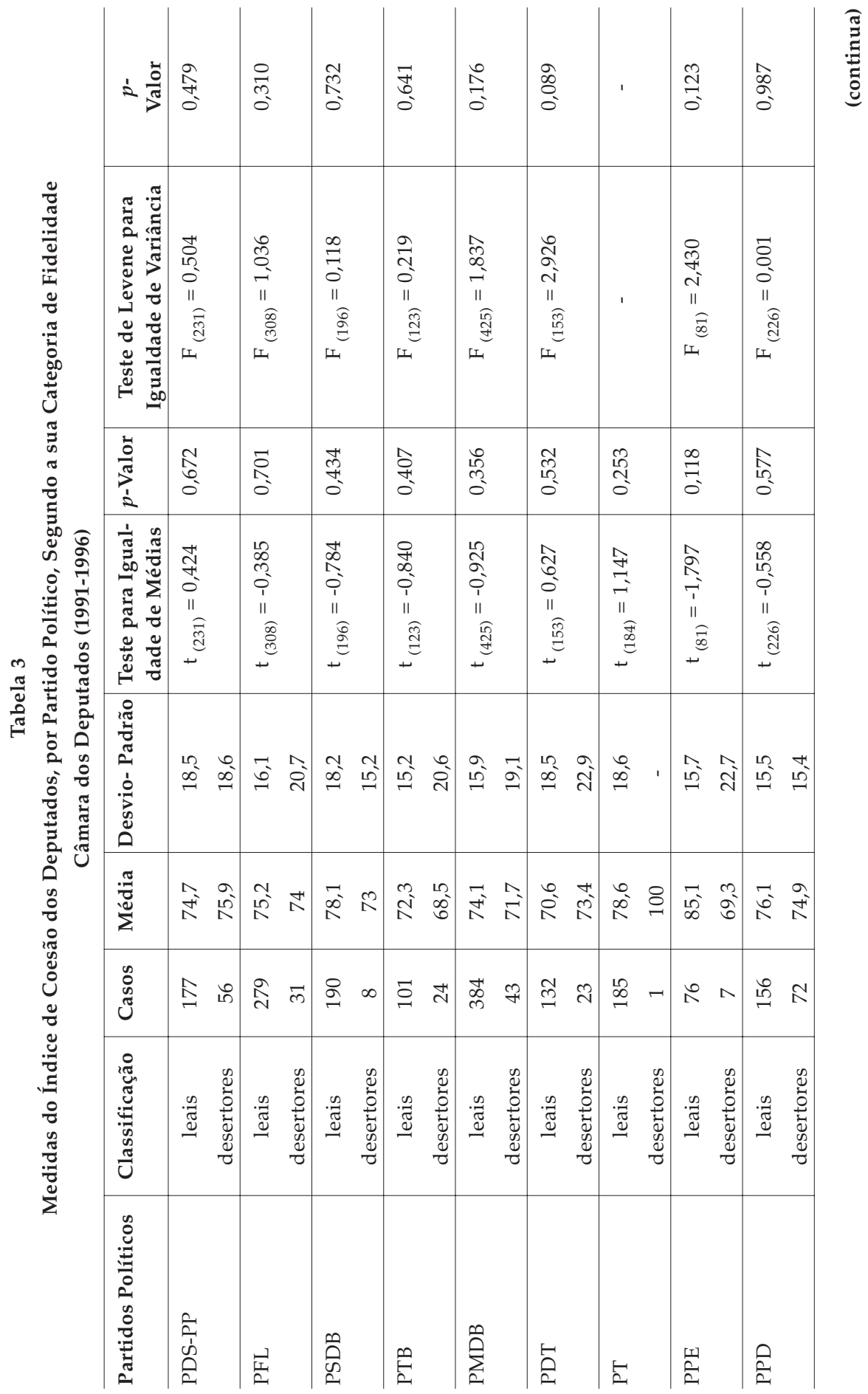


Os Efeitos da Migração Interpartidária na Conduta Parlamentar

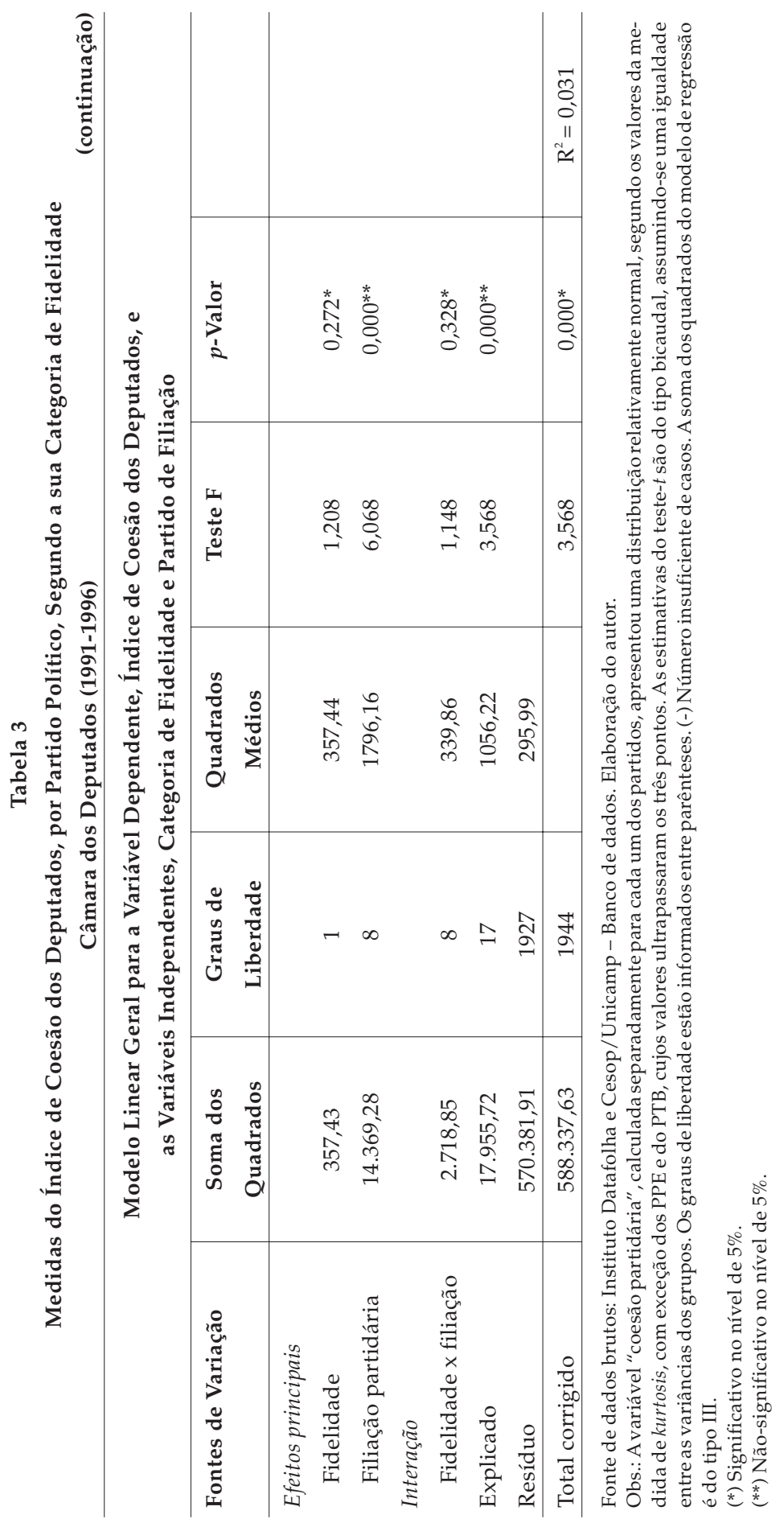


PT, o único deputado que migrou era mais partidário do que os seus colegas. No que se refere aos demais partidos - PDS/PPR/PPB/PP (pequenos partidos de direita - PPD), PFL, PMDB e PDT -, leais e desertores são igualmente coesos. Os testes estatísticos apontam que, dentro das bancadas partidárias, não existe diferença significativa entre migrantes e não-migrantes. Existe, na verdade, diferença entre os partidos. Embora todas as legendas sejam internamente coesas, ou seja, seus deputados manifestam pontos de vista comuns sobre os temas que compõem a agenda parlamentar, elas se diferenciam. O PT e os pequenos partidos de esquerda destacam-se por alcançar um nível de coesão acima da média, enquanto o PTB e o PDT, por obterem níveis abaixo dela. Os resultados atestam que o índice de coesão dos parlamentares varia de acordo com o partido de filiação, mas não quanto à sua categoria de fidelidade

A Tabela 4 discrimina, por legislatura, os índices de disciplina ${ }^{6}$ obtidos pelos deputados leais nos partidos de filiação e os índices dos desertores nos partidos aos quais estavam filiados antes de migrar e nos partidos em que ingressaram. As tabulações da taxa de disciplina variam de 0 a 100. A subtração entre as duas primeiras linhas revela o contraste entre migrantes e não-migrantes; a da segunda e da terceira linhas, a

Tabela 4

Média e Coeficiente de Variação do Índice de Disciplina dos Deputados, por Legislatura, Segundo a Categoria de Fidelidade Partidária

Câmara dos Deputados (1988-2004)

\begin{tabular}{|c|c|c|c|c|c|c|c|c|c|c|}
\hline \multirow{3}{*}{$\begin{array}{l}\text { Categoria dos } \\
\text { Deputados }\end{array}$} & \multicolumn{10}{|c|}{ Legislatura } \\
\hline & \multicolumn{2}{|c|}{$48^{\mathrm{a}}$} & \multicolumn{2}{|c|}{$49^{a}$} & \multicolumn{2}{|c|}{$50^{\mathrm{a}}$} & \multicolumn{2}{|c|}{$51^{\mathrm{a}}$} & \multicolumn{2}{|c|}{$52^{\mathrm{a}}$} \\
\hline & $\begin{array}{l}\text { Mé- } \\
\text { dia }\end{array}$ & $\begin{array}{c}\text { Varia- } \\
\text { ção }\end{array}$ & $\begin{array}{l}\text { Mé- } \\
\text { dia }\end{array}$ & $\begin{array}{c}\text { Varia- } \\
\text { ção }\end{array}$ & $\begin{array}{l}\text { Mé- } \\
\text { dia }\end{array}$ & $\begin{array}{l}\text { Varia- } \\
\text { ção }\end{array}$ & $\begin{array}{l}\text { Mé- } \\
\text { dia }\end{array}$ & $\begin{array}{c}\text { Varia- } \\
\text { ção }\end{array}$ & $\begin{array}{l}\text { Mé- } \\
\text { dia }\end{array}$ & $\begin{array}{l}\text { Varia- } \\
\text { ção }\end{array}$ \\
\hline $\begin{array}{l}\text { Leais, no parti- } \\
\text { do de filiação }\end{array}$ & 87,6 & 15 & 89,6 & 10,9 & 90,1 & 14,7 & 92,4 & 14,4 & 89 & 20,2 \\
\hline $\begin{array}{l}\text { Desertores, no } \\
\text { partido do qual } \\
\text { migrou }\end{array}$ & 84,3 & 21,1 & 86,2 & 15,3 & 87,5 & 18,7 & 89,3 & 17,7 & 81,9 & 27,9 \\
\hline $\begin{array}{l}\text { Desertores, } \\
\text { no(s) partido(s) } \\
\text { em que ingres- } \\
\text { sou }\end{array}$ & 87,2 & 17,3 & 86,1 & 17,4 & 88,4 & 15,1 & 89 & 17,6 & 86,5 & 22,7 \\
\hline
\end{tabular}

Fonte de dados brutos: Cebrap - Banco de dados Votação Nominal da Câmara dos Deputados. Elaboração do autor.

Obs.: O número de casos consta da Tabela A1 do Apêndice. 
diferença dos níveis de disciplina dos deputados migrantes antes e depois da troca de partido. Os índices dos três agrupamentos são elevados e situam-se no mesmo nível. Os coeficientes de variância apontam para a homogeneidade interna desses grupos. Deputados leais ou desertores votam de forma concordante com a orientação dos líderes do partido ao qual estiverem filiados. É necessário destacar que os desertores eram disciplinados no partido que abandonaram e continuaram se comportando dessa maneira nos partidos aos quais se filiaram ${ }^{7}$.

A Tabela 5 descreve, por legislatura, os índices de disciplina obtidos pelos deputados leais e desertores, levando-se em conta a sua filiação partidária. Esta ilustração apresenta, na primeira coluna, a taxa de disciplina dos deputados leais ao partido no qual estavam filiados; na segunda, a dos desertores no partido do qual se desligaram; e, na terceira coluna, a dos desertores depois da mudança. Para facilitar a exposição, somente as maiores siglas foram discriminadas, e os pequenos partidos, agrupados de acordo com seu matiz ideológico.

Como se observa nesta ilustração, a diferença de disciplina entre migrantes e não-migrantes é bem pequena, mesmo considerando-se o partido de filiação. Os deputados imigrantes continuam sendo disciplinados em outros partidos, em um nível muito próximo do revelado naquele do qual se desligou. Suas taxas de disciplina são bem parecidas e seguem o padrão estabelecido no partido de origem. O resíduo entre as taxas varia cerca de cinco pontos percentuais em praticamente todas as legislaturas e em todos os partidos. Por outro lado, um pequeno grupo de deputados mais indisciplinado do que o restante da bancada partidária da qual se desligou, motivado por essa discordância, buscou outro partido mais adequado ao seu perfil, tornando-se mais disciplinado. Na 52a legislatura, um pequeno grupo de deputados discordou dos encaminhamentos dos líderes do seu partido em comparação com o restante da sua bancada. Esses emigrantes, oriundos do PSDB, PFL e PT, mostraram-se mais indisciplinados do que o restante da bancada. Em se tratando do PFL, os deputados leais apresentaram uma taxa de disciplina 15 pontos superior à dos desertores; no caso do PSDB, essa diferença atingiu a marca de 22,8 pontos percentuais e foi ainda maior no PT, 23,3 pontos. No caso dos deputados que migram por discordar do posicionamento do seu partido, eles votavam de modo indisciplinado e, depois de manifestarem seu descontentamento, ingressaram em um partido da coalizão rival e obedeceram às orien- 


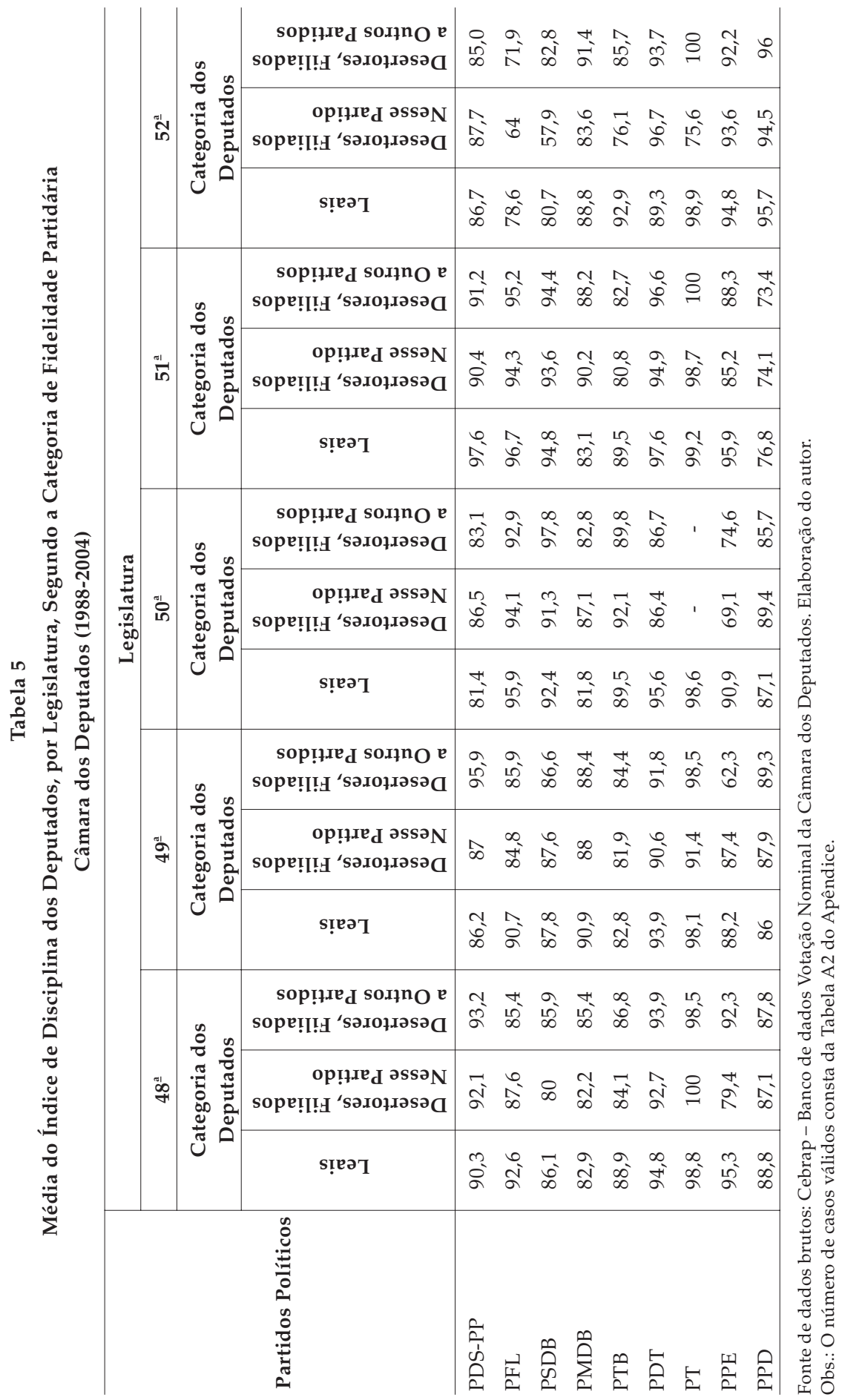


tações dos seus novos líderes em um grau mais elevado. Esses casos, todavia, constituem desvios da regra, como pode ser provado na análise da próxima ilustração.

A Tabela 6 apresenta, para cada uma das legislaturas, os testes sobre a influência da categoria de fidelidade e da filiação partidária sobre os índices de disciplina que os deputados obtiveram nas votações. Os estimadores apontam que a filiação partidária é uma variável importante para explicar a variação das taxas de unidade dos deputados e, ademais, eles são significativos estatisticamente em todo o período analisado (inclusive para a 52 legislatura). Por sua vez, os testes relativos à categoria de fidelidade tiveram resultados opostos. Essas duas variáveis não interagem, quer dizer, os deputados leais e os desertores apresentam desempenho semelhante, dentro de cada um dos partidos, quanto ao indicador de disciplina.

Avaliados em conjunto, esses indicadores de partidarismo comprovam que os deputados, sejam eles leais ou desertores, exprimem idéias convergentes com sua bancada em relação à agenda do seu partido e ao mesmo tempo obedecem às orientações dos líderes nas votações do plenário da Câmara. O desempenho dos agrupamentos nesse quesito pode ser considerado muito positivo. Sem dúvida, os parlamentares não podem justificar a sua mudança de filiação por motivos relacionados à discordância programática ou ao problema de relacionamento com os seus líderes, visto que os migrantes, assim como seus correligionários, estavam bem situados na legenda à qual estiveram filiados.

\section{MUDANÇAS DE PARTIDO E SEU IMPACTO COMPORTAMENTAL}

Esta seção avalia a consistência da migração interpartidária e os efeitos que as mudanças de filiação têm na conduta dos parlamentares ${ }^{8}$. Primeiro, os partidos foram classificados no mapa da ideologia por dois critérios: o posicionamento dos líderes do partido no conjunto de votações do plenário e as respostas da sua bancada de deputados a um conjunto de perguntas sobre a agenda política. Depois, a migração interpartidária é qualificada como consistente, quando as legendas envolvidas pertencem ao mesmo campo político, ou inconsistente, quando a barreira da ideologia é ultrapassada. Em seguida, foram comparados os escores de ideologia e unidade que os deputados auferiram antes e depois da deserção partidária. Considera-se, enfim, que a troca de par- 


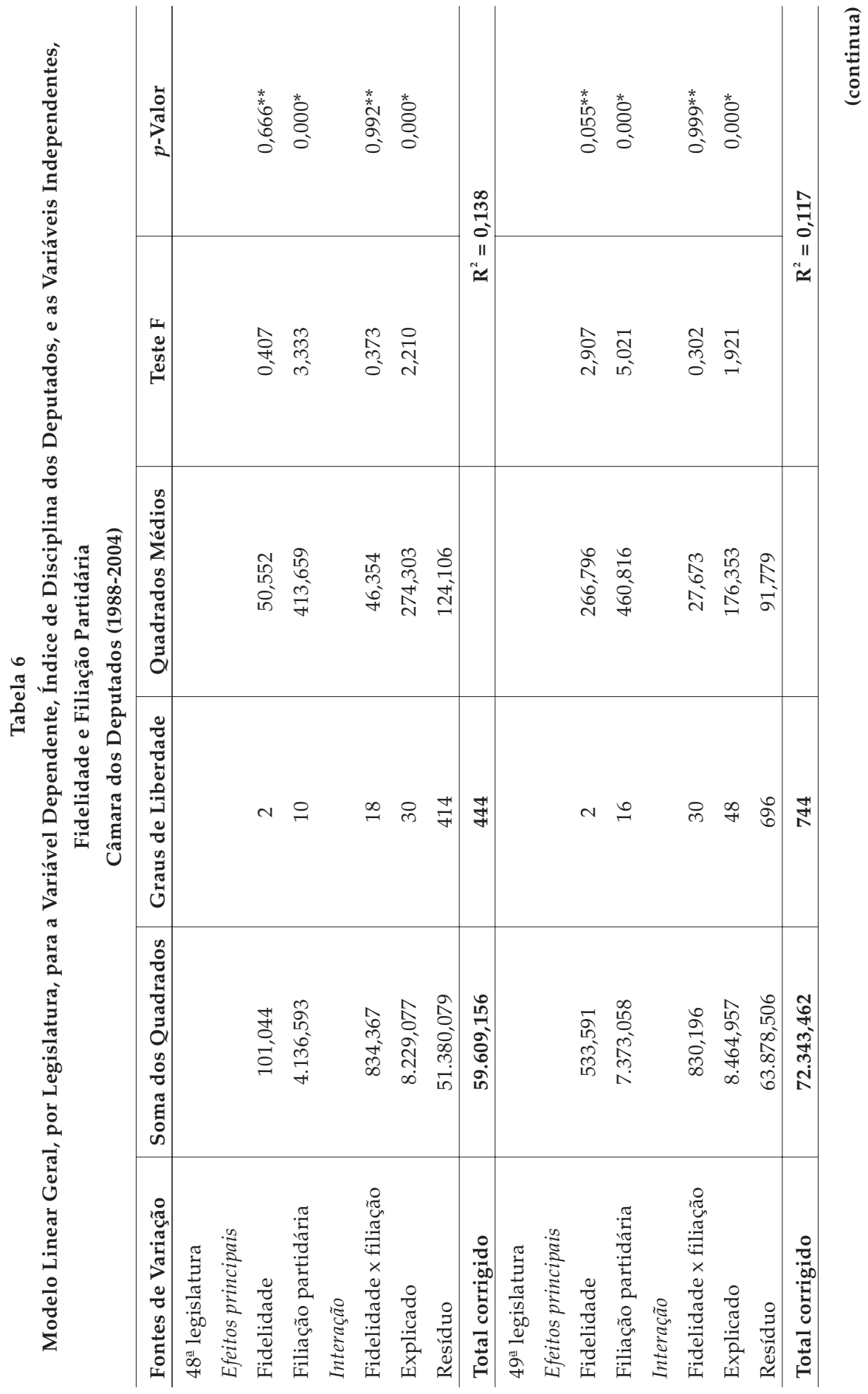


Os Efeitos da Migração Interpartidária na Conduta Parlamentar

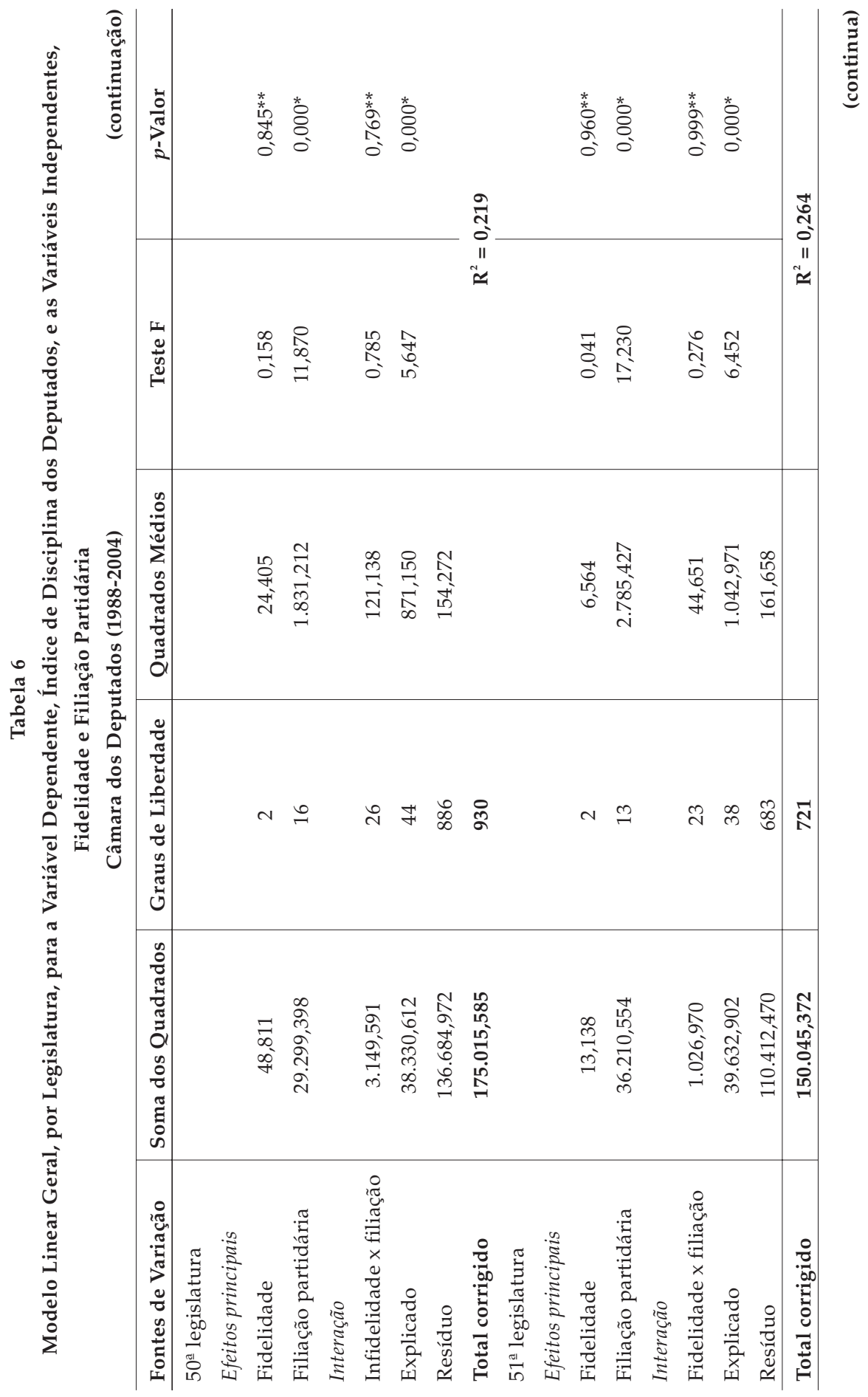




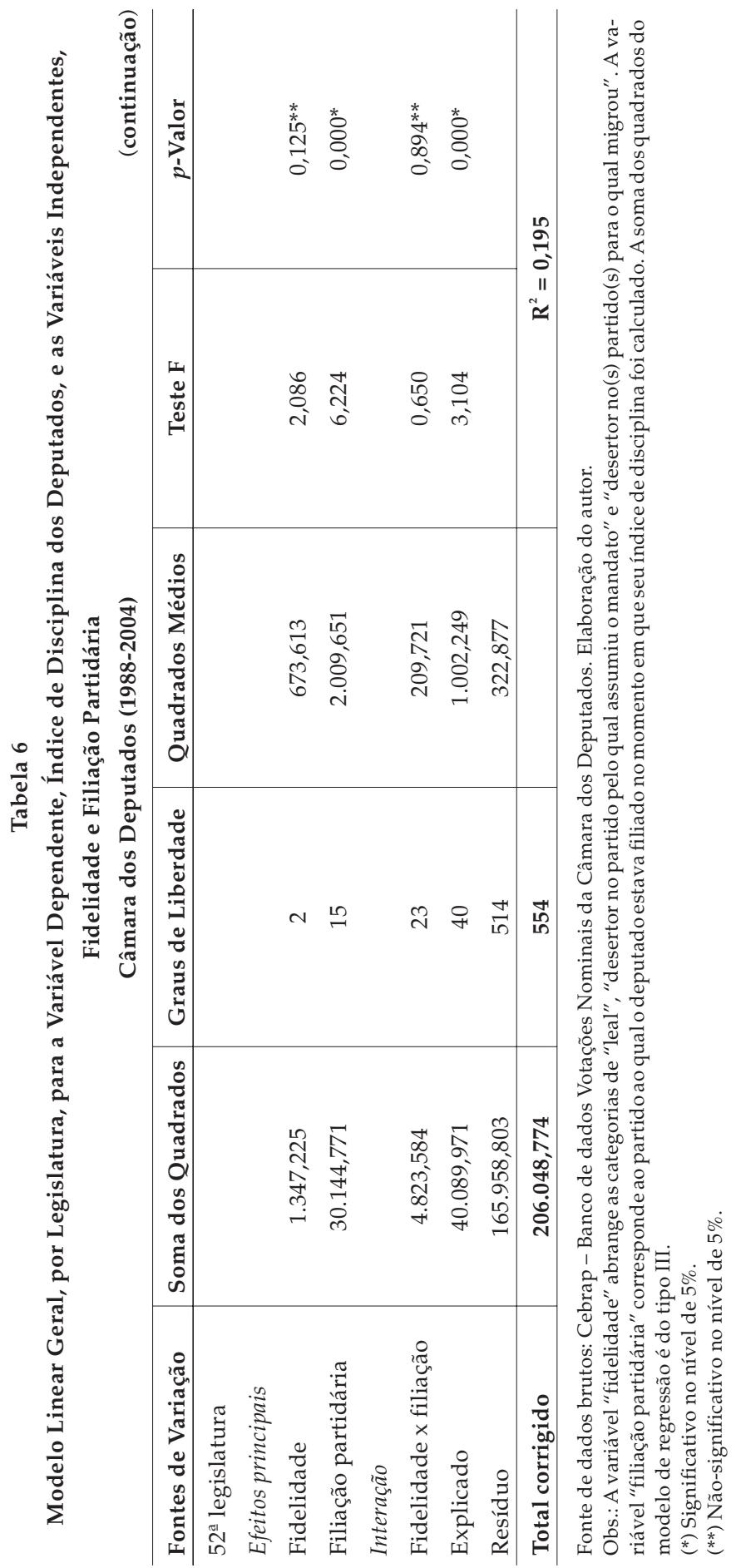


tido produz mudança na conduta parlamentar quando a diferença entre esses escores é grande e significativa estatisticamente.

A Tabela 7 mostra que as trocas de partido têm um sentido consistente, levando-se em conta o critério da afinidade de ideário entre as legendas ${ }^{9}$. Os desertores escolhem uma alternativa de filiação compatível com o seu perfil político. Mais de dois terços do total de migrantes entraram e saíram de partidos contíguos no espectro ideológico. Por levar em conta esse parâmetro em suas escolhas, a maioria deles pode manter suas crenças no partido novo, conforme demonstram as taxas elevadas de coesão antes e depois da migração. Em se tratando dos migrantes entre os blocos de direita e esquerda, as trocas de filiação serviram para eles melhorarem o seu índice de coesão em mais de 10 pontos percentuais. Apenas nesses casos, os deputados podem justificar o seu desligamento como decorrente de discordância programática, visto que ingressaram em um partido com o qual tinham mais afinidade.

Tabela 7

Índice de Coesão dos Deputados Migrantes, por Partido de Eleição e de Filiação, Segundo o Tipo de Migração Câmara dos Deputados (1991-1996)

\begin{tabular}{l|c|c|c}
\hline Tipo de Migração & Partido de Eleição & Partido de Filiação & Casos Válidos \\
\hline Consistente & 73,5 & 70 & $(161)$ \\
Centro $\leftrightarrow$ centro & 65,6 & 65,4 & 12 \\
Direita $\leftrightarrow$ direita & 70,1 & 73,8 & 146 \\
Esquerda $\leftrightarrow$ Esquerda & 90 & 85,9 & 3 \\
Inconsistente & 63 & 71,7 & $(92)$ \\
Centro $\leftrightarrow$ direita & 62,1 & 71,9 & 63 \\
Centro $\leftrightarrow$ esquerda & 67,2 & 65,7 & 9 \\
Direita $\leftrightarrow$ esquerda & 63,8 & 73,6 & 20 \\
\hline Total & $\mathbf{6 7 , 5}$ & $\mathbf{7 2 , 8}$ & $\mathbf{( 2 5 3 )}$ \\
\hline
\end{tabular}

Fonte de dados brutos: Instituto Datafolha e Cesop/Unicamp - Banco de dados. Elaboração do autor.

Obs.: As trocas de partido foram consideradas "consistentes" quando ocorreram entre partidos situados na mesma posição ideológica. Veja Tabela A2 no Apêndice.

A Tabela 8 apreende as diferenças das taxas de coesão dos migrantes, computadas antes e depois da troca de partido. O sentido da migração, se consistente ou não, altera tanto as médias como as variâncias desse indicador de partidarismo. A diferença média da coesão dos deputados que ultrapassaram a barreira da ideologia é o dobro daquela dos 
deputados que a respeitaram. De fato, apenas os parlamentares que transitaram entre partidos de esquerda e direita se diferenciam dos demais nesse quesito.

Tabela 8

Medidas das Diferenças dos Índices de Coesão dos Deputados Migrantes, Calculados Antes e Depois da Troca de Partido, Segundo o Tipo de Migração

Câmara dos Deputados (1991-1996)

\begin{tabular}{l|c|c|c|c|c|c|c}
\hline $\begin{array}{l}\text { Tipo de Mi- } \\
\text { gração }\end{array}$ & Casos & Média & $\begin{array}{c}\text { Desvio- } \\
\text { Padrão }\end{array}$ & $\begin{array}{c}\text { Teste } \\
\text { para } \\
\text { Igualda- } \\
\text { de de } \\
\text { Médias }\end{array}$ & $p$-Valor & $\begin{array}{c}\text { Teste de } \\
\text { Levene } \\
\text { para } \\
\text { Igualda- } \\
\text { de de } \\
\text { Variân- } \\
\text { cia }\end{array}$ & $p$-Valor \\
\hline Consistente & 161 & 8,10 & 10,3 & $\mathrm{t}_{(251)}=$ & 0,000 & $\mathrm{~F}_{(251)}=$ & 0,000 \\
Inconsistente & 92 & 15,4 & 15,3 & $-4,539$ & & 14,812 & \\
\hline Total & 253 & & & & & & \\
\hline
\end{tabular}

Fonte de dados brutos: Instituto Datafolha e Cesop/Unicamp - Banco de dados. Elaboração do autor.

Obs.: A variável "diferença de escores" apresentou uma distribuição relativamente normal. Os graus de liberdade do numerador e do denominador estão entre parênteses. Foi utilizado o teste de Tukey para identificar o grupo de migrantes cuja taxa de coesão destoava dos demais.

A Tabela 9 faz a checagem dos escores de ideologia dos deputados migrantes, estimados tanto no partido do qual saíram como no partido em que ingressaram. O resultado é que os desertores mantêm seu posicionamento no partido novo. Isto significa que, apesar de terem mudado de filiação, continuam votando com a antiga coalizão a qual pertence o partido que os elegeu. Confirmando a classificação anterior baseada no ideário dos partidos, a grande maioria dos deputados entra e sai de legendas localizadas à direita do mapa de votações da Câmara. De cada 10 migrantes, apenas um se movimenta entre os partidos localizados nas extremidades desse mapeamento. Os testes reforçam que o sentido da migração interpartidária, quando considerado consistente ou inconsistente, influencia a mudança de comportamento dos migrantes.

A Tabela 10 descreve, por legislatura, as correlações dos escores de ideologia dos deputados migrantes, computados nos partidos de origem e destino. O primeiro indicador é o coeficiente de correlação, que atinge o valor - 1 quando os desertores invertem seu posicionamento no novo partido, e 1, quando o mantêm. O segundo indicador é a medida 
Os Efeitos da Migração Interpartidária na Conduta Parlamentar

Tabela 9

Diferença Média dos Escores de Ideologia dos Deputados Migrantes, Segundo a Classificação Ideológica do Partido de Origem e de Destino

Câmara dos Deputados (1991-2004)

\begin{tabular}{|c|c|c|c|c|c|}
\hline \multirow{2}{*}{ Bloco de Origem } & \multicolumn{4}{|c|}{ Bloco de Destino } & \multirow{2}{*}{ Total } \\
\hline & \multicolumn{2}{|c|}{ Esquerda } & Centro & Direita & \\
\hline Esquerda & \multicolumn{2}{|c|}{$\begin{array}{c}0,07 \\
15 \\
(3,7 \%) \\
\end{array}$} & $\begin{array}{c}0,08 \\
8 \\
(2 \%) \\
\end{array}$ & $\begin{array}{c}0,23 \\
24 \\
(5,9 \%)\end{array}$ & 47 \\
\hline Centro & \multicolumn{2}{|c|}{$\begin{array}{c}0,17 \\
16 \\
(4 \%) \\
\end{array}$} & $\begin{array}{c}0,22 \\
3 \\
(1 \%) \\
\end{array}$ & $\begin{array}{c}0,21 \\
17 \\
(4,2 \%) \\
\end{array}$ & 36 \\
\hline Direita & \multicolumn{2}{|c|}{$\begin{array}{c}0,19 \\
24 \\
(5,9 \%) \\
\end{array}$} & $\begin{array}{c}0,12 \\
32 \\
(7,9 \%) \\
\end{array}$ & $\begin{array}{c}0,08 \\
263 \\
(65,4 \%) \\
\end{array}$ & 319 \\
\hline Total & \multicolumn{2}{|c|}{55} & 43 & 304 & $\begin{array}{c}402 \\
(100 \%)\end{array}$ \\
\hline Tipo de Migração & Casos & Média & Desvio- Padrão & $\begin{array}{c}\text { Teste } \\
\text { Kruskal-Wallis }\end{array}$ & $\begin{array}{c}p- \\
\text { Valor }\end{array}$ \\
\hline $\begin{array}{l}\text { Consistente } \\
\text { Inconsistente }\end{array}$ & $\begin{array}{l}281 \\
121\end{array}$ & $\begin{array}{l}0,084 \\
0,175\end{array}$ & $\begin{array}{l}0,077 \\
0,167\end{array}$ & $x_{(1)}^{2}=31,736$ & 0,000 \\
\hline Total & 402 & 0,111 & 0,120 & & \\
\hline
\end{tabular}

Fonte de dados brutos: Cebrap - Banco de dados Votação Nominal da Câmara dos Deputados. Elaboração do autor.

Obs.: Os partidos foram classificados em três categorias: esquerda (de - 0,26 até - 1 ), centro (de - 0,25 até $0,25)$ e direita (de 0,26 até 1 ). A classificação da origem e do destino baseia-se nos escores obtidos pelos líderes de acordo com seus encaminhamentos em plenário. A estimativa dos pontos ideais é feita somente para os deputados que votaram pelo menos 20 vezes ou mais no partido de origem e de destino. As mudanças múltiplas foram desconsideradas. A variável "diferença" é a subtração entre os pontos ideais dos deputados nos partidos de origem e de destino. Ela não apresentou uma distribuição, pois os valores da medida de kurtosis superaram quatro pontos. Por isso, utilizou-se um teste não-paramétrico.

de distância ideológica, que inclui o valor 0 se os desertores permanecem no mesmo ponto do espectro ideológico; e 1, se percorrem o intervalo máximo entre as extremidades da escala. De acordo com as evidências apresentadas, muitos deputados migrantes representam, no partido de destino, um ponto ideal bem semelhante àquele revelado no partido de origem. Nas 49aㅗ $50^{a}$ e $51^{\underline{a}}$ legislaturas, os migrantes pouco se deslocaram no espaço político, perfazendo uma distância bem pequena. Esses índices são elevados e significativos. Isto demonstra que, apesar da mudança de filiação, os deputados continuam se posicionando nas votações do mesmo modo. A 52a registra o impacto dos movimentos entre partidos que integram diferentes coalizões. Um 
grupo de desertores rompeu a barreira da ideologia e inverteu seu posicionamento nas votações. Suas estimativas, contudo, devem ser analisadas com cautela, pois não são significativas e dependem de casos extremos que contaminam o restante das observações. Na última legislatura, os partidos dirigiram-se ao centro do espectro ideológico, diminuindo a distância a ser percorrida pelos migrantes de uma legenda à outra $^{10}$.

Tabela 10

Correlação e Diferença dos Escores de Ideologia dos Migrantes, Calculados Antes e Depois da Troca de Partido, por Legislatura Câmara dos Deputados (1991-2004)

\begin{tabular}{l|c|c|c|c|c}
\hline \multirow{2}{*}{ Medidas } & \multicolumn{5}{|c}{ Legislaturas } \\
\cline { 2 - 6 } & $\mathbf{4 9 ^ { \mathbf { a } } \text { Collor }}$ & $\mathbf{4 9 ^ { \underline { a } }}$ Itamar & $\mathbf{5 0}^{\underline{\mathbf{a}}}$ & $\mathbf{5 1}^{\mathbf{a}}$ & $\mathbf{5 2}^{\mathbf{a}}$ \\
\hline Coeficiente & 0,53 & 0,54 & 0,67 & 0,58 & $-0,08$ \\
p-Valor & $0,000^{*}$ & $0,001^{*}$ & $0,000^{*}$ & $0,000^{*}$ & $0,538^{* *}$ \\
Distância média & 0,10 & 0,09 & 0,09 & 0,08 & 0,26 \\
Casos válidos & 47 & 37 & 154 & 106 & 58 \\
\hline
\end{tabular}

Fonte de dados: Cebrap - Banco de dados Votação Nominal da Câmara dos Deputados. Elaboração do autor.

Obs.: O índice de distância varia de 0 a 1 e é calculado pela fórmula: ID $=\Sigma|(A-B) / 2|$ onde "A" é o ponto ideal no partido de origem, e " $\mathrm{B}$ " é o ponto ideal no partido de destino. A 48a legislatura foi excluída dessa análise devido ao baixo número de votações nominais.

(*) Significativo no nível de 5\%.

(**) Não-significativo.

A Tabela 11 aponta que as diferenças médias entre os escores de ideologia dos deputados migrantes dependem dos partidos de origem e de destino. Quanto mais díspares forem os partidos envolvidos na migração, maiores serão as diferenças a serem observadas. As maiores distâncias entre os pontos ideais dos deputados foram observadas entre os pequenos partidos de direita e os pequenos partidos de esquerda; entre o PDT e o PTB; entre o PDS-PP e os pequenos partidos de esquerda; reconhecidamente partidos que se opõem nas votações em plenário. Por outro lado, as menores distâncias foram anotadas entre os deputados que se deslocaram entre o PFL e o PSDB; o PMDB e o PSDB; o PDS-PP e os pequenos de direita. Do total, apenas 22,9\% deles (92 em 402) revelaram que os deputados inverteram o sinal dos seus escores de ideologia. Registrou-se o maior número de desertores que saltaram de um campo político a outro entre as siglas localizadas nas extremidades do mapa de votações. Em alguns desses casos, os migrantes já votavam, no partido de origem, em concordância com o posiciona- 
Os Efeitos da Migração Interpartidária na Conduta Parlamentar

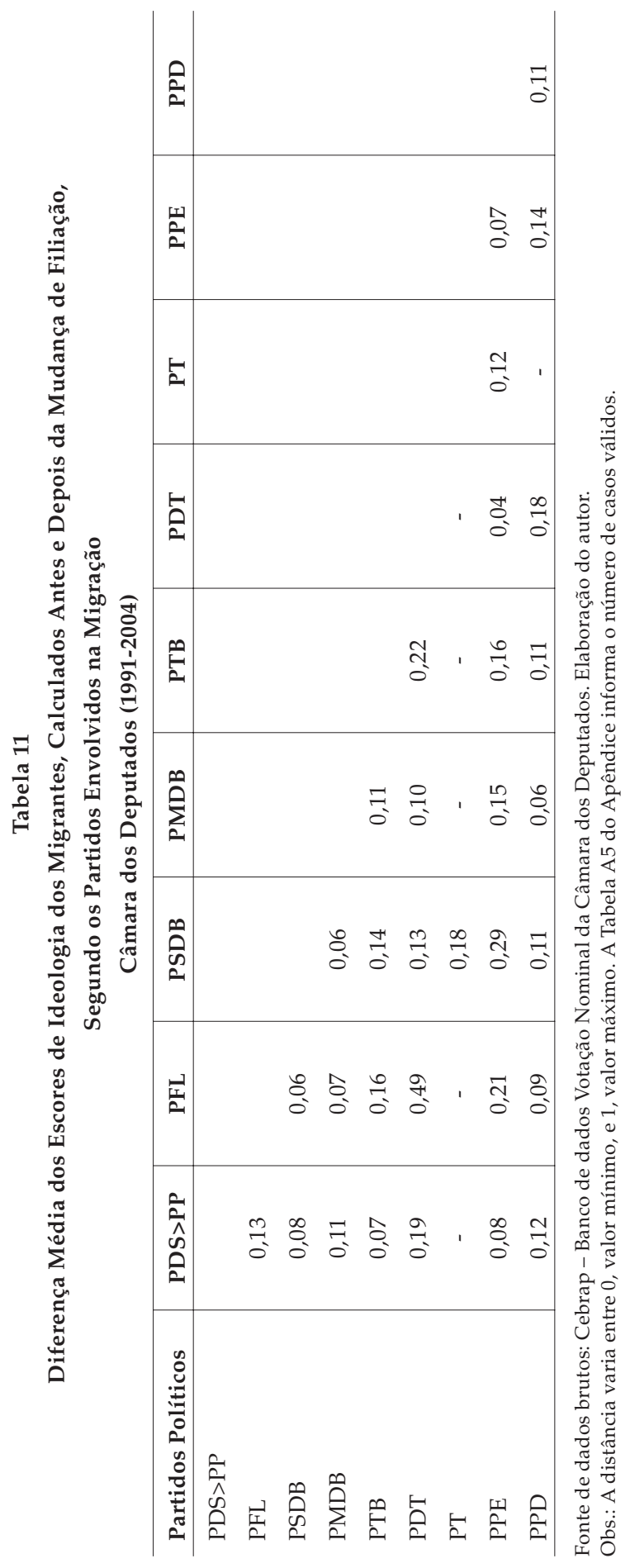


mento do partido de destino, sendo desnecessária a mudança de comportamento.

A movimentação de parlamentares entre os partidos revela-se altamente coerente do ponto de vista ideológico. Eles trocam de partido, mas, na prática, continuam expressando os mesmos ideais e votando de igual maneira. Embora a proporção de desertores se revele alta em termo absoluto e seja motivada por seus interesses individuais, o número daqueles que ultrapassam a fronteira da ideologia é bem reduzido, na medida em que implica abandonar a defesa das preferências dos seus eleitores, enfrentando as conseqüências nas urnas; apresentar-se ao público com outro discurso, manifestando incoerência; e conviver com parlamentares com os quais rivalizavam nas votações, enfrentando a desconfiança deles. Para contornar esses obstáculos, os emigrantes escolhem uma alternativa de filiação partidária apropriada ao seu matiz político. Quando os deputados se movimentam dentro de um bloco, como ocorre na maioria das vezes, eles não precisam se converter a uma nova doutrina. Eleitores tampouco têm motivos para castigá-los nas urnas, visto que os migrantes mantiveram sua posição política e se comportaram nas votações de maneira coerente.

Esse padrão de infidelidade partidária pode ser explicado pela estrutura da Câmara dos Deputados, caracterizada pelo multipartidarismo e pela semelhança entre muitas das legendas, que incentivam os parlamentares a trocarem de partido freqüentemente, sem enfrentar resistências dos seus novos correligionários e dos seus velhos eleitores. A magnitude e os efeitos das trocas de partido são diferentes em uma câmara legislativa cuja composição se concentra em duas legendas polarizadas no contínuo ideológico, pois, nesse caso, os parlamentares têm poucas alternativas de filiação e precisam percorrer uma grande distância de um partido a outro. A Câmara dos Representantes norte-americana é um caso exemplar desse tipo de modelo. Seus parlamentares raramente mudam de partido, mas, quando o fazem, alteram o seu posicionamento político e, agindo dessa maneira, descumprem as promessas feitas ao eleitorado. Em tal contexto, as trocas de partido desvirtuam a lógica do sistema representativo. Uma comparação entre Brasil e Estados Unidos ilustrará esse último ponto.

\section{DESERÇÃO PARTIDÁRIA EM PERSPECTIVA COMPARADA}

As câmaras baixas do Brasil e dos Estados Unidos desenham, aparentemente, um cenário propício para que os parlamentares mudem sua 
filiação partidária. A legislação de ambos os países permite essa prática. Suas organizações partidárias são frágeis se comparadas a modelos de sistema parlamentarista e carecem de instrumentos legais que reforcem a lealdade dos seus filiados. Os líderes dos partidos controlam, na arena legislativa, o acesso a recursos e a cargos das casas legislativas que podem ser usados para incentivar o ingresso de deputados em seus partidos de filiação. Apesar de terem esses aspectos em comum, as câmaras brasileira e norte-americana apresentam processos migratórios radicalmente distintos.

O primeiro contraste entre ambas está no volume das mudanças de partido. A Câmara brasileira, atualmente composta por 513 deputados, registra centenas de desertores nos últimos 20 anos. A House of Representatives, constituída de 435 deputados, contabiliza 72 casos em um século e meio de história parlamentar. Raramente os deputados do Partido Republicano, do Partido Democrata ou os independentes trocam sua filiação. De 1879 a 1945, apenas 48 deputados desligaram-se do seu partido para se filiar a outro; de 1946 a 1987, 16; de 1988 a 1999, apenas oito. Em média, dois deputados migram a cada legislatura. $\mathrm{O}$ registro de mudança múltipla também é raro. Apenas nove deputados trocaram de sigla por duas vezes. Desde 1945, nenhuma mudança múltipla de filiação é registrada ${ }^{11}$. Levando-se em conta a série histórica da migração partidária, podemos notar que o fator tempo desempenha diferentes papéis nas câmaras brasileira e norte-americana. Na primeira, observa-se uma oscilação no número de deputados migrantes nas sucessivas legislaturas; na segunda, o número de migrantes é regular ao longo dos anos, mantendo-se inclusive imutável por décadas. A fidelidade dos parlamentares estadunidenses é verificada desde a formação do sistema partidário e, assim, não pode ser creditada à sua longevidade.

A Tabela 12 faz a contagem dos deputados migrantes, identificando os agrupamentos de origem e destino. Proporcionalmente, os deputados de pequenos agrupamentos e os independentes são os que mais trocam de legenda, seguidos pelos republicanos e, em último lugar, pelos democratas. O sentido dessa movimentação atesta que os democratas tendem a se filiar ao rival enquanto os republicanos, aos pequenos agrupamentos. Os deputados minoritários deslocam-se mais vezes para o Partido Republicano do que para o Partido Democrata, e apenas um deles preferiu se filiar à outra legenda minoritária. Em que pesem os poucos casos observados, o trânsito de deputados entre os maiores 
partidos é incoerente do ponto de vista ideológico, uma vez que eles marcam historicamente posições opostas nas votações do Congresso (ver Cooper e Young, 2002) e, ao longo dos últimos anos, essa polarização no espectro político se tornou mais acirrada (Poole e Rosenthal, 1997) $)^{12}$.

Tabela 12

Número de Deputados que Trocaram de Legenda,

Segundo os Partidos de Origem e de Destino

Câmara dos Representantes - Estados Unidos (1879-1999)

\begin{tabular}{|c|c|c|c|c|c|}
\hline & \multicolumn{4}{|c|}{ Destino } \\
\hline & & $\begin{array}{l}\text { Partido Re- } \\
\text { publicano }\end{array}$ & $\begin{array}{l}\text { Independentes e } \\
\text { Demais Grupos }\end{array}$ & $\begin{array}{l}\text { Partido De- } \\
\text { mocrata }\end{array}$ & Total \\
\hline \multirow{4}{*}{ Origem } & $\begin{array}{c}\text { Partido } \\
\text { Democrata }\end{array}$ & 17 & 4 & & 21 \\
\hline & $\begin{array}{c}\text { Partido } \\
\text { Republicano }\end{array}$ & & 18 & 9 & 27 \\
\hline & $\begin{array}{l}\text { Independen- } \\
\text { tes e demais } \\
\text { grupos }\end{array}$ & 20 & 1 & 12 & 33 \\
\hline & Total & 37 & 23 & 21 & 81 \\
\hline
\end{tabular}

Fonte de dados brutos: Voteview - Banco de dados Roll-call Voting in House of Representatives. Elaboração do autor.

Obs.: Dois deputados foram recontados, pois mudaram de partido por duas vezes em diferentes legislaturas.

A segunda diferença entre a câmara brasileira e a norte-americana refere-se aos fatores que induzem os parlamentares a mudarem de partido. Deputados brasileiros motivam-se por recursos ou cargos, ou ainda, pelos interesses particulares ligados à carreira parlamentar, mais precisamente, verbas orçamentárias, candidaturas, tempo de exposição na propaganda eleitoral e postos da organização legislativa. Diferentemente, na Câmara dos Representantes, os deputados mudam de filiação por divergência a respeito do posicionamento do seu partido no que se refere ao conflito militar e ao papel do Estado na economia (Nokken, 2000; Castle e Fett, 2000; Nokken e Poole, 2001).

A Tabela 13 apresenta indícios de que a desavença de natureza programática é a principal justificativa para um deputado abandonar o seu partido e ingressar em outro. Não há uma forte tendência de os deputados buscarem ingressar no partido majoritário ou do governo. Em vez disso, a maioria dos migrantes da Câmara Baixa sai do partido gover- 
nista e entra no de oposição. Há exemplos de movimentos de parlamentares oriundos do partido governista para o partido de oposição inclusive quando o presidente da República tinha, reconhecidamente, popularidade alta entre os eleitores.

Tabela 13

Número de Deputados Migrantes, Segundo o Tamanho e a Situação dos Partidos Envolvidos na Migração

Câmara dos Representantes - Estados Unidos

Pela Posição do Partido (1899-1999)

\begin{tabular}{c|l|c|c|c|c}
\hline \multicolumn{2}{c|}{} & \multicolumn{4}{c}{ Destino } \\
\cline { 3 - 6 } \multicolumn{2}{c|}{} & Majoritário & Minoritário & Demais Grupos & Total \\
\hline \multirow{4}{*}{ Origem } & Majoritário & & 11 & 5 & 16 \\
& Minoritário & 13 & & 11 & 24 \\
& Demais grupos & 15 & 9 & 1 & 25 \\
\cline { 2 - 6 } & Total & $\mathbf{2 8}$ & $\mathbf{2 0}$ & $\mathbf{1 7}$ & $\mathbf{6 5}$ \\
\hline
\end{tabular}

Quanto à Posição em Relação ao Presidente da República (1879-1999)

\begin{tabular}{c|l|c|c|c|c}
\hline \multicolumn{2}{c|}{} & \multicolumn{4}{c}{ Destino } \\
\cline { 3 - 6 } \multicolumn{2}{c|}{} & Governista & Oposicionista & Demais Grupos & Total \\
\hline \multirow{4}{*}{ Origem } & Governista & & 20 & 8 & 28 \\
& Oposicionista & 7 & & 13 & 20 \\
& Demais grupos & 13 & 19 & 1 & 33 \\
\cline { 2 - 6 } & Total & $\mathbf{2 0}$ & $\mathbf{3 9}$ & $\mathbf{2 2}$ & $\mathbf{8 1}$ \\
\hline
\end{tabular}

Fonte de dados brutos: Voteview - Banco de dados Roll-call Voting in House of Representatives. Elaboração do autor.

Obs.: O partido majoritário é o que detém a maior bancada. O segundo maior partido é tido como minoritário. O partido governista é aquele ao qual o presidente da República está filiado no exercício do seu mandato. Durante esse período, todos os presidentes pertenceram ou ao Partido Republicano ou ao Partido Democrata. O “oposicionista" é o segundo maior partido.

Nesse período, em que os líderes do partido majoritário eram democratas ou republicanos, apenas metade dos desertores buscou se filiar a algum deles. Mas a migração de parlamentares para o partido majoritário não é dominante, e o movimento parece ser justamente o oposto. Dezesseis deputados saíram do partido majoritário para integrar o partido minoritário ou tornar-se independentes. Dentre os deputados oriundos dos pequenos agrupamentos, 15 ingressaram no partido majoritário, nove dirigiram-se ao partido minoritário, e apenas um tornou-se independente. 
A terceira diferença entre as casas legislativas do Brasil e dos Estados Unidos está em seus efeitos na correlação de forças partidárias e no comportamento dos deputados durante as votações. Na Câmara dos Deputados, as mudanças de filiação pouco alteram o tamanho das coalizões, pelo fato de a movimentação entre os partidos ocorrer intrabloco ideológico e de os migrantes manterem sua disciplina no partido novo. Na Câmara dos Representantes, as mudanças de sigla significam o enfraquecimento do partido que elegeu o deputado e a transferência de poder ao oponente, especialmente quando as cadeiras estão distribuídas entre o Partido Republicano e o Partido Democrata, em uma divisão paritária. A movimentação entre as siglas democrata e republicana também altera o comportamento dos deputados nas votações.

O conteúdo da Tabela 14 corrobora a hipótese de que existe diferença comportamental entre os migrantes que se movimentam entre os partidos majoritários e os que transitam por agrupamentos minoritários. As medidas que testam o impacto da troca de partido no posicionamento espacial dos deputados são as correlações entre os escores dos deputados no partido antigo e no partido novo e as médias das diferenças entre um e outro. Se os valores forem próximos ao número zero, os deputados migrantes mudaram seu comportamento nas votações; caso contrário, os deputados mantiveram a sua maneira de votar. Como podemos observar, a média da diferença quanto ao primeiro grupo de migrantes é o dobro da média do segundo grupo. Essa desigualdade pode ser confirmada nas duas dimensões que organizam o mapa das votações ${ }^{13}$. Confirmando o resultado anterior, a correlação entre os pontos ideais dos deputados que transitam entre o Partido Democrata e o Partido Republicano são bem menores na primeira dimensão - que é a mais importante do mapa espacial -, comprovando que houve uma alteração significativa do seu comportamento nas votações. Quando a deserção ocorre tendo como origem ou destino os pequenos agrupamentos, os deputados reproduzem o seu ponto ideal no partido novo ${ }^{14}$.

De um total de 53 migrantes advindos dos pequenos agrupamentos, apenas 11 alteraram seu comportamento no plenário, invertendo, no novo partido, o sinal do seu ponto ideal ${ }^{15}$. Os demais mantiveram seu padrão de votação, mesmo porque já tinham afinidade ideológica, conforme pode ser comprovado pela correspondência entre seu ponto ideal no partido de origem e no partido de destino ${ }^{16}$. De maneira diversa, os deputados que transitaram entre o Partido Republicano e o Partido 
Tabela 14

Medidas Descritivas dos Escores de Ideologia dos Deputados Migrantes, Segundo o Tipo de Partidos Envolvidos na Migração Câmara dos Representantes - Estados Unidos (1879-1999)

\begin{tabular}{|c|c|c|c|c|}
\hline Agrupamentos Partidários & Casos & $\begin{array}{c}\text { Média da } \\
\text { Distância entre } \\
\text { os Escores } \\
\text { Iniciais e Finais } \\
\end{array}$ & $\begin{array}{l}\text { Desvio- } \\
\text { Padrão }\end{array}$ & $\begin{array}{c}\text { Correlação } \\
\text { entre os } \\
\text { Pontos Ideais } \\
\text { (r de Pearson) }\end{array}$ \\
\hline \multicolumn{5}{|l|}{$1^{\underline{a}}$ dimensão } \\
\hline $\begin{array}{l}\text { Partido Democrata } \\
\downarrow\end{array}$ & 27 & 0,182 & 0,089 & 0,135 \\
\hline Partido Republicano & & & & \\
\hline $\begin{array}{l}\text { Democratas ou Republicanos } \\
\downarrow \\
\text { Grupos minoritários }\end{array}$ & 54 & 0,073 & 0,081 & 0,806 \\
\hline $\begin{array}{l}\text { Total } \\
2^{\underline{a}} \text { dimensão }\end{array}$ & 81 & 0,110 & 0,098 & \\
\hline $\begin{array}{l}\text { Partido Democrata } \\
\downarrow \\
\text { Partido Republicano }\end{array}$ & 27 & 0,280 & 0,173 & 0,428 \\
\hline $\begin{array}{l}\text { Democratas ou republicanos } \\
\downarrow \\
\text { Grupos minoritários } \\
\end{array}$ & 54 & 0,130 & 0,153 & 0,671 \\
\hline Total & 81 & 0,221 & 0,164 & \\
\hline
\end{tabular}

Fonte de dados brutos: Voteview - Banco de dados Roll-call Voting in House of Representatives. Elaboração do autor.

Obs.: O índice de distância é calculado da seguinte maneira: ID $=\Sigma$ I (ponto ideal A - ponto ideal B) $/ 2$ I.

Democrata alteraram sua conduta nas votações. A grande maioria desses migrantes passou a concordar com as novas orientações partidárias ( 25 em 27 casos). Esse efeito comportamental independe do partido de origem e de destino. Do conjunto, 16 deputados alteraram o sinal do seu ponto ideal, passando da esquerda para a direita, no caso de democratas que se tornaram republicanos, ou passando da direita para a esquerda, em se tratando de republicanos que se tornaram democratas. Desses migrantes, nove já votavam em concordância grande com o partido rival e, depois de ingressarem nele, passaram a apoiar ainda mais o novo partido. Esses casos, porém, são insuficientes para ameaçar o sistema representativo como um todo, porque a proporção de mi- 
grantes em relação ao conjunto de parlamentares é muito pequena, e a de republicanos ou democratas, irrisória.

Esses efeitos da infidelidade partidária na Câmara dos Representantes podem ser justificados de duas maneiras. Em primeiro lugar, os migrantes podem ser considerados como dissidentes em outro partido caso não aceitem as orientações dos líderes do seu novo partido e, comportando-se dessa forma, atendam às expectativas de seus novos correligionários. Em segundo lugar, os parlamentares infiéis tendem a ser rejeitados pelos eleitores do seu distrito se não os convencerem de que eles se converteram politicamente. Os candidatos cujo sistema de crenças destoa da sua sigla de filiação têm probabilidade alta de fracassar nas convenções primárias do Partido Democrata ou Republicano (Burden, 2004). Além disso, os migrantes têm um desempenho eleitoral pior quando comparados aos não-migrantes (Grose, 2003) ${ }^{17}$. Os desertores são, portanto, induzidos a se ajustarem à ideologia do partido no qual ingressaram, almejando conquistar a preferência dos novos eleitores, evitar problemas de convivência com seus novos partidários e aumentar as chances de serem reeleitos.

Esse modelo de infidelidade partidária pode ser explicado pelo arranjo partidário dos Estados Unidos. Seus parlamentares têm basicamente duas alternativas de filiação, o Partido Democrata e o Partido Republicano, e estas legendas estão cada vez mais polarizadas ideologicamente. Com esses obstáculos, poucos parlamentares mudam sua filiação partidária no exercício do seu mandato, ainda que possam fazê-lo. Contando a partir da terceira formação do sistema partidário, menos de 80 deputados trocaram de partido enquanto exerciam seu mandato na Câmara Baixa. Os emigrantes, além de se justificarem ao público alegando divergência programática a respeito de temas-chave da agenda, precisam apoiar as iniciativas do novo partido; caso contrário, são punidos pelos eleitores e correligionários do seu distrito e dificilmente se reelegem, o principal objetivo de suas carreiras. O problema é que, quando mudam suas crenças e sua maneira de votar, os deputados desertores descumprem o compromisso assumido com o seu eleitorado, qual seja, o de representar determinada posição política. Conseqüentemente, a composição ideológica da Câmara dos Representantes deixa de ser condizente com as escolhas feitas pelo eleitorado, descaracterizando uma das funções do sistema representativo, que é a de reproduzir, na esfera legislativa, a estrutura de preferências dos eleitores. 


\section{CONSIDERAÇÕES FINAIS}

Os estudos anteriores sobre fidelidade partidária na Câmara dos Deputados alertaram para a sua magnitude e as suas causas. A partir dessas contribuições, sabemos que os mandatários freqüentemente trocam de partido, motivados por circunstâncias que facilitem atingir os objetivos de sua carreira, como a reeleição e a ocupação de postos na esfera governamental. As mudanças de filiação distorcem a representatividade que as legendas obtiveram depois de as urnas serem fechadas e os votos serem traduzidos em cadeiras e impedem que os parlamentares firmem carreira em apenas uma legenda.

Esse diagnóstico, não obstante esteja correto, desconsidera o desempenho dos deputados migrantes no quesito partidarismo e os efeitos das mudanças de filiação em seu comportamento. Deputados leais ou desertores têm um desempenho similar no cumprimento das obrigações assumidas com o partido ao qual estavam filiados. Os dois agrupamentos apóiam a agenda partidária, obtendo notas parecidas nos quesitos disciplina e coesão. A maior parte da movimentação interpartidária é consistente do ponto de vista ideológico. Mais de dois terços das mudanças de partido ocorreram dentro de um bloco, seja ele de esquerda, de centro ou de direita. De cada 10 migrantes, apenas um rompeu essa barreira de maneira drástica, transitando de partidos esquerdistas para os direitistas ou o contrário. Muitos deputados trocam de partido, mas, apesar disso, continuam marcando uma posição política compatível com aquela sinalizada pelo partido pelo qual se elegeram. Portanto, a infidelidade partidária é menos nociva à representação das preferências dos eleitores do que se convenciona acreditar.

As mudanças de filiação tampouco servem de indicativo de fraqueza das organizações partidárias. Os partidos têm um processo de recrutamento eficiente ao ponto de selecionarem candidatos que partilham do seu programa e que, uma vez eleitos, se mostram comprometidos em defender seu ideário e em aprovar as iniciativas do seu partido nas votações do plenário da Câmara. Os deputados infiéis estavam bem alocados na sigla pela qual assumiram o seu mandato e, dentre as múltiplas alternativas de filiação, escolhem aquela cuja ideologia se assemelha à do partido que os elegeu.

O debate no Brasil sobre a infidelidade partidária limita-se muitas vezes às questões normativas em torno de um imperativo segundo o qual o representante deve manter-se filiado sempre a um partido político 
durante o exercício do seu mandato, quando não, durante toda a sua carreira. Esse princípio, no qual os críticos se apóiam, incentiva a proposição de inúmeros projetos de reforma da legislação, em especial o estabelecimento de regras que forcem os mandatários a permanecerem leais à sua legenda. No entanto, as trocas de partido podem ser reduzidas sem a adoção de regulamentos que desrespeitem o direito à liberdade de associação política, como aqueles que vigoraram no autoritarismo das décadas precedentes. O caso dos Estados Unidos serve como referência de país que combina uma legislação permissiva com a observância de lealdade partidária por parte dos seus parlamentares.

Para alcançar esse objetivo, os partidos brasileiros poderiam, em curto prazo, dificultar a entrada de políticos oriundos de outras legendas, instituir em seus estatutos um prazo de reserva para um filiado advindo de outro partido e solicitar ao órgão competente a aplicação dos mecanismos de punição previstos na Lei dos Partidos Políticos no 9.065, de 1995, como os artigos 25 e 26, que prevêem, além de outras penalidades, a perda automática da função ou cargo que exerça, na respectiva Casa Legislativa, o parlamentar que deixar o partido por cuja legenda tenha sido eleito. A solução de longo prazo consiste em reduzir o número de legendas com representatividade nas câmaras Baixa e Alta, de modo que a mudança de partido implique o custo de mudar de posicionamento político e enfrentar a rejeição dos seus eleitores.

Por certo, se não forem aplicadas medidas restritivas, os parlamentares continuarão a trocar de partido em busca de vantagens pessoais para promover suas carreiras políticas. No entanto, esta análise mostra que os efeitos da infidelidade partidária são menos deletérios para o sistema representativo brasileiro do que alegam estudos baseados apenas na magnitude e nas motivações das mudanças de legenda.

(Recebido para publicação em junho de 2006) (Versão definitiva em março de 2007) 


\section{NOTAS}

1. O Brasil destaca-se negativamente com relação ao número de casos de infidelidade partidária, mesmo se comparado a países cuja legislação também tolera essa prática, como Estados Unidos, Itália ou Espanha (ver Maciel, 2004). Tomando-se como exemplo a Espanha, 90 parlamentares trocaram de partido, totalizando 104 movimentações registradas no Congreso de los Diputados entre 1977 e 1989. Com a consolidação do sistema partidário, caracterizada principalmente pelo predomínio do Partido Socialista Espanhol - PSOE e do Partido Popular - PP, o número de migrantes caiu para três, um e oito, respectivamente, na quarta (1989-1993), quinta (1993-1996) e sexta (1996-2000) legislaturas. Para obter mais detalhes sobre os números e as características da infidelidade partidária na Espanha, consulte Tomás Mallén (2002).

2. O número de parlamentares desertores varia de acordo com o partido. Essa variabilidade põe em xeque as abordagens sistêmicas que focalizam a legislação em vigor ou fatores endógenos ao processo legislativo. O PT e as pequenas siglas de esquerda, diferentemente dos demais, implantam regras de convivência que dificultam a entrada e a saída de filiados em seus quadros. Esses regulamentos internos podem explicar por que ele registra baixo número de entrada e saída de filiados. A organização petista mantém um estatuto cujo conteúdo incentiva seus filiados a serem leais à legenda, e seu arcabouço normativo faz com que cultivem laços mais fortes com a legenda, além de impedir a entrada de políticos oportunistas. No governo Lula, os migrantes preferiram rumar para o $\mathrm{PL}$, o PP ou o PTB, pois não estavam dispostos a arcar com o ônus de pertencer à organização petista. Em contraste, o PSDB apresenta uma movimentação intensa de filiados em seus quadros. Nos dois mandatos do governo Fernando Henrique, o partido facilitou o ingresso de vários políticos, aumentando, dessa maneira, a sua representatividade. Agora, na oposição, o partido perdeu cerca de um terço dos seus deputados. Para uma comparação entre PT e PSDB, veja Roma (2006a).

3. Limongi e Freitas (2005) apresentam evidências de que o sentido das trocas de partido no eixo governo/oposição é altamente consistente, ou seja, somente uma minoria de desertores transita entre os dois pólos. Ademais, a maioria dos deputados migrantes já estava sob influência do Poder Executivo e apoiava as iniciativas do presidente da República nas votações em plenário. Também é preciso considerar, nesse estudo, a porcentagem expressiva de parlamentares oriundos de partidos governistas que rumaram para a oposição.

4. Esse tópico é controverso. Segundo os mesmos estudos, a relação entre fidelidade partidária e volatilidade eleitoral confirma-se apenas em alguns estados do país. Os deputados que trocam de partido três ou mais vezes têm a mesma probabilidade de reeleição dos fiéis a sua legenda. Na verdade, a punição dos eleitores torna-se clara apenas quando seus representantes passam a defender uma bandeira política diferente daquela do partido que o elegeu. Há outro argumento a ser considerado nessa discussão. Se os migrantes corressem os riscos de não serem reeleitos, dificilmente observaríamos um número tão exagerado e persistente de trocas de partido.

5. Os dados de coesão partidária provêm de um conjunto de levantamentos de opinião parlamentar. A pesquisa "Pré-plebiscito no Congresso Nacional" foi realizada entre 4 e 6 de junho de 1991, reunindo um conjunto de 21 questões sobre forma de governo, presidencialismo ou parlamentarismo, o uso das medidas provisórias, bicameralis- 


\section{Celso Roma}

mo, voto facultativo para os eleitores, cláusula de barreira mínima no Congresso Nacional, pena de morte e outras. O levantamento de dados "Impeachment Presidente Congresso Nacional" foi feito entre os dias 6 e 7 de julho de 1992, agregando sete perguntas sobre o impedimento do presidente da República, o desempenho do presidente diante da crise e a sua sucessão. A pesquisa "Congresso Nacional - Reeleição" ocorreu entre os dias 10 e 17 de outubro de 1993, tratando de 27 temas, como o direito de reeleição para presidente da República, governadores de Estado e prefeitos e o sistema eleitoral, o número de deputados por Estado, entre outros. O survey "Congresso Nacional", entre 21 de fevereiro e 14 de março de 1995, questionou os parlamentares quanto a temas referentes ao funcionamento do Congresso Nacional, instituições eleitorais e políticas públicas, através de um questionário com 21 perguntas. A sondagem "Congresso Nacional - Reeleição I" foi registrada entre os dias 10 e 17 de outubro de 1996 e a "Congresso Nacional - Reeleição", entre 8 e 10 de janeiro de 1997, reunindo, respectivamente, cinco e oito perguntas. Ambas tratam dos mesmos temas: o direito de reeleição e o trâmite da emenda da reeleição, o desempenho do presidente e a maneira de mudar essa lei. Todas as pesquisas de opinião foram realizadas pelo instituto Datafolha. Os temas foram selecionados pelos critérios de divergência mínima. Incluíram-se as perguntas cuja concentração de respostas em uma alternativa foi menor do que 90. A taxa de coesão é a média das porcentagens modais com relação ao conjunto de respostas de um determinado grupo. Outras informações estão disponíveis em Roma (2006b).

6. As informações sobre o comportamento dos deputados provêm do banco de dados "Votações Nominais na Câmara dos Deputados", depositado no Centro Brasileiro de Análise e Planejamento - Cebrap e utilizado por Figueiredo e Limongi (1999). Na minha análise, foram incluídos os deputados que votaram ao menos 10 vezes em uma determinada legislatura. A taxa de disciplina partidária é relativa, pois leva em conta somente os votos válidos. Para os deputados que migraram mais de uma vez em uma legislatura, a taxa de disciplina foi computada para o conjunto de partidos aos quais estiveram filiados. $\mathrm{O}$ índice de disciplina dos parlamentares diz respeito à proporção de votos que coincidiram com os encaminhamentos dos líderes do seu partido. Faltas e abstenções foram retiradas do cálculo desse indicador. A exclusão dessas informações não compromete a análise proposta, uma vez que deputados desertores ou fiéis apresentam, também, taxas semelhantes de faltas e de abstenção.

7. Esses resultados divergem daqueles observados no período de atividade da Assembléia Nacional Constituinte. Por meio da análise das votações nominais registradas entre 1986 e 1988, Mainwaring e Pérez Liñan (1998) constataram que a taxa de disciplina dos parlamentares aumentava após a mudança de filiação partidária.

8. Melo (2000) e Desposato (2006) já demonstraram que as trocas de partido na Câmara dos Deputados são ideologicamente consistentes. Diferenciando-se dos anteriores, minha pesquisa contempla, além das votações nominais, os levantamentos de opinião parlamentar cuja análise permite mensurar as preferências dos deputados em um contexto no qual as instituições estão ausentes. Tal estratégia possibilita classificar, com rigor, os partidos no espectro ideológico e interpretar, com clareza, o sentido da movimentação de parlamentares entre os partidos.

9. Os escores de ideologia dos deputados foram estimados utilizando-se a rotina W-NOMINATE. Essa técnica já havia sido usada por Leoni (2002) e atualizada por Roma (2006c). Para uma discussão sobre o modelo espacial e as fórmulas estatísticas, 
veja Poole (2005). Somente os deputados que votaram ao menos 20 vezes foram incluídos na estimação desses escores. A pontuação dos deputados é calculada com base em seus votos nominais registrados em uma legislatura. Os valores dos escores variam entre - 1 e 1 . Levando-os em conta, os partidos foram classificados em três categorias: esquerda (de $-0,26$ até -1 ), centro (de $-0,25$ até 0,25 ) e direita (de 0,26 até 1 ). Nas sondagens de 1991 a 1993, correspondendo à 49aํ legislatura, o PT, o PDT, o PSB, o PMN, o PPS e o PC do B foram classificados como de esquerda; PMDB, PSDB, PL, PST, PTB, de centro; PDS/PPR/PPB/PP, PTR, PDC, PP, PRT, PSL, PSC, PRN e PRP, como de direita; nas sondagens realizadas em 1995 e em 1996, o PFL, o PSDB, o PMDB, o PL, o PTB, o PSC, o PST, o Prona, o PSL, à direita; o PSD e o PV, ao centro; e o PT, o PDT, o PMN e o PPS, à esquerda. Como há mudanças múltiplas de partido, considerei somente os pontos ideais dos parlamentares em relação ao primeiro e ao último partido ao qual estiveram filiados.

10. Veja o Gráfico A1 do Apêndice. Para uma descrição do realinhamento ideológico na Câmara dos Deputados, veja Roma (2006c).

11. Ness e Ciment (2000) revisam a origem e os formatos do sistema partidário dos Estados Unidos. Esta análise limita-se a sua terceira e atual formação, caracterizada pelo predomínio de democratas e republicanos. As informações sobre a migração interpartidária nos Estados Unidos procedem do banco de dados Roll-call Voting in House of Representatives, elaborado por Keith T. Poole e disponibilizado no endereço eletrônico http:/ / voteview.com.

12. Veja o Gráfico A2 no Apêndice. Há semelhança entre as câmaras baixas dos Estados Unidos e da Espanha no que se refere à motivação e aos efeitos da infidelidade partidária. O estudo de Mershon e Heller (2003) mostra que as trocas de partido na Câmara Baixa da Espanha não podem ser motivadas pela busca de cargos no governo ou por reeleição. Os partidos de oposição foram os mais beneficiados, mesmo estando afastados do gabinete ministerial e tendo a perspectiva de sofrerem derrotas nas eleições (o que, de fato, aconteceu). Os desertores têm chances menores de se reelegerem, sobretudo se migram para a coalizão rival. Isto indica que os parlamentares desertam por conflito de opinião, mesmo tendo que enfrentar reveses nas urnas.

13. A rotina NOMINATE, em sua versão dinâmica, é considerada como a mais adequada para estimar os pontos ideais dos parlamentares da Câmara dos Representantes, porque a série histórica de votações é longa. As estimativas de um mapa com duas dimensões justificam-se pelo fato de que somente nos últimos 50 anos o modelo se tornou robusto com apenas uma dimensão. Para uma discussão desse assunto, veja Poole (2005).

14. Comparando-se o formato dos gráficos A1 e A2 do Apêndice, podemos visualizar que a distância percorrida pelos deputados que migram entre as legendas republicana e democrata seria equivalente à distância a ser percorrida entre um deputado do PT que resolvesse ingressar no PFL ou vice-versa. Nota-se, ainda, que nos últimos anos o sistema partidário norte-americano está se polarizando, enquanto o brasileiro, moderando-se. A conseqüência disto é que, salvo alguma mudança relevante na legislação desses países, o número de mudanças de partido continuará baixo na Câmara norte-americana e alto, na brasileira.

15. Trata-se de um democrata que se tornou independente; três republicanos que ingressaram no Silver Republican; um progressista, no Partido Democrata, um indepen- 


\section{Celso Roma}

dente republicano, no Partido Republicano; um American Labor, no Partido Democrata; três republicanos, nos progressistas e outro, no American Labor.

16. Entre eles, três democratas que saíram para se tornarem independentes democratas ou independentes; 10 republicanos, para os progressistas, independentes, independentes republicanos, Farmer Labor e American Labor; 11 progressistas, para o Partido Republicano ou Partido Democrata; seis independentes democratas, para o Partido Democrata; quatro independentes republicanos, para o Partido Republicano e o Farmer Labor; dois Reajuster, para o Partido Republicano; do National Green, para o Partido Republicano e outro para o Democrata; um independente e um do Silver, para o Partido Democrata; um do Union Labor para o Farmer Labor; um do Farmer Labor para o Partido Republicano; e, finalmente, um liberal, para o Partido Democrata.

17. Os desertores somente conseguem reverter o seu declínio nas eleições a longo prazo e quando passam a ter uma atuação destacada em postos importantes da organização interna do Poder Legislativo, especialmente na Mesa Diretora e nas comissões (Grose e Yoshinaka, 2003). Essas evidências sugerem que a oferta de recursos e cargos no governo que os líderes dos partidos controlam é insuficiente para fazer com que os parlamentares troquem de partido. Os problemas a serem enfrentados pelos desertores nas urnas parecem ter um peso maior em sua decisão de permanecerem leais ao seu partido.

\section{REFERÊNCIAS BIBLIOGRÁFICAS}

ARAÚJO, Marcelo. (2000), Mudanças Partidárias: A Evolução das Migrações Partidárias na Câmara dos Deputados. Dissertação de mestrado em Ciência Política, USP, São Paulo.

BURDEN, Barry C. (2004), "Candidate Positioning in US Congressional Elections". British Journal of Political Science, vol. 34, no 2, pp. 211-227.

CASTLE, David e FETT, Patrick. (2000), “Member Goals and Party Switching in the US Congress", in W. T. Bianco (org.), Congress on Display, Congress at Work. Ann Arbor, University of Michigan Press, pp. 231-241.

COOPER, Joseph e YOUNG, Garry. (2002), "Party and Preference in Congressional Decision Making: Roll Call Voting in the House of Representatives", in D. W. Brady e M. D. McCubbins (orgs.), Party, Process, and Political Change in Congress - New Perspectives on the History of Congress. Stanford, Stanford University Press, pp. 64-106.

DESPOSATO, Scott W. (2006), "Parties for Rent? Ambition, Ideology, and Party Switching in Brazil's Chamber of Deputies". American Journal of Political Science, vol. 50, no 1, pp. 62-80. 
DINIZ, Simone. (2000), “As Migrações Partidárias e o Calendário Eleitoral”. Revista de Sociologia e Política, no 15, pp. 31-47.

FIGUEIREDO, Argelina e LIMONGI, Fernando. (1999), Executivo e Legislativo na Nova Ordem Constitucional (1a ed.). Rio de Janeiro, Editora FGV.

GROSE, Christian R. (2003), Is it Rational to Switch Parties? Long-Term versus Short-Term Electoral Effects of Legislative Party Switching. Trabalho apresentado na reunião anual da Midwest Political Science Association, Chicago, 3-6 de abril.

e YOSHINAKA, Antoine. (2003), “The Electoral Consequences of Party Switching by Incumbent Members of Congress, 1947-2000". Legislative Studies Quarterly, vol. 28, no 1, pp. 55-75.

LEONI, Eduardo. (2002), “Ideologia, Democracia e Comportamento Parlamentar: A Câmara dos Deputados (1991-1998)". Dados, vol. 45, no 3, pp. 361-386.

LIMA JUNIOR, Olavo Brasil de. (1993), Democracia e Instituições Políticas no Brasil dos Anos 80. São Paulo, Loyola.

LIMONGI, Fernando e FREITAS, Andréa. (2005), “Migração Partidária e Comportamento Legislativo". Anais do XXIX Encontro Anual da Anpocs, Caxambu, 25-29 de outubro (CD-ROM).

MACIEL, Eliane C. B. de. (2004), “Fidelidade Partidária: Um Panorama Institucional". Textos para Discussão no 9, Brasília, Consultoria Legislativa do Senado Federal.

MAINWARING, Scott. (1999), Rethinking Party Systems in the Third Wave of Democratization: The Case of Brazil. Stanford, Stanford University Press.

e PÉREZ LIÑAN, Aníbal. (1998), “Disciplina Partidária: O Caso da Constituinte”. Lua Nova, no 44, pp. 107-136.

MARENCO DOS SANTOS, André. (2001), "Sedimentação de Lealdades Partidárias no Brasil: Tendências e Descompassos". Revista Brasileira de Ciências Sociais, vol. 16, no 45, pp. 69-83.

MELO, Carlos Ranulfo Félix de. (2000), “Partidos e Migração Partidária na Câmara dos Deputados". Dados, vol. 43, no 2, pp. 207-239.

. (2004), Retirando as Cadeiras do Lugar: Migração Partidária na Câmara dos Deputados (1985/2002). Belo Horizonte, Editora UFMG.

MERSHON, Carol e HELLER, William B. (2003), Party Switching and Political Careers in the Spanish Congress of Deputies, 1982-1996. Trabalho apresentado na reunião anual da Midwest Political Science Association. Chicago, 3-6 de abril.

NESS, Immanuel e CIMENT, James (orgs.). (2000), The Encyclopedia of Third Parties in America. Armonk, Sharpe Reference.

NICOLAU, Jairo M. (1996), “A Migração Partidária na Câmara dos Deputados (1991-96)". Monitor Público, ano 3, vol. 3, no 10, pp. 41-45.

NOKKEN, Timothy. (2000), "Dynamics of Congressional Loyalty: Party Defection and Roll-Call Behavior, 1947-1997". Legislative Studies Quarterly, vol. 25, no3, pp. 417-444. e POOLE, Keith T. (2001), Congressional Party Defection in American History. Trabalho apresentado na reunião anual da American Political Science Association, São Francisco, 30 de agosto-2 de setembro. 


\section{Celso Roma}

POOLE, Keith T. (2005), Spatial Models of Parliamentary Voting. New York/Cambridge, Cambridge University Press.

e ROSENTHAL, Howard. (1997), Congress: A Political-Economic History of Roll-Call Voting. New York, Oxford University Press.

ROMA, Celso. (2006a), “Organizaciones de Partido en Brasil: El PT y el PSDB Bajo Perspectiva Comparada". América Latina Hoy - Revista de Ciencias Sociales, vol. 44, pp. 153-184.

(2006b), "Agenda, Ideologia e Coesão Partidária na Câmara dos Deputados". Anais do XXX Encontro Anual da Anpocs, Caxambu, 24-28 de outubro (CD-ROM).

. (2006c), “O Mapa da Ideologia da Câmara dos Deputados". Valor Econômico, 25 de outubro, p. A12.

SCHMITT, Rogério. (1999), “Migração Partidária e Reeleição na Câmara dos Deputados". Novos Estudos Cebrap, no 54, pp. 127-146.

TOMÁS MALLÉN, Beatriz. (2002), Transfuguismo Parlamentario y Democracia de Partidos. Madrid, Centro de Estudios Políticos y Constitucionales. 
Os Efeitos da Migração Interpartidária na Conduta Parlamentar

\section{APÊNDICE}

Tabela A1

Número e Porcentagem de Deputados Migrantes Identificados nas Pesquisas de Opinião, Segundo a Classificação Ideológica dos Partidos

Envolvidos na Migração

Câmara dos Deputados (1991-1996)

\begin{tabular}{|c|c|c|c|c|c|}
\hline \multirow{2}{*}{\multicolumn{2}{|c|}{ Blocos }} & \multicolumn{3}{|c|}{ Destino } & \multirow{2}{*}{ Total } \\
\hline & & Esquerda & Centro & Direita & \\
\hline \multirow{3}{*}{ Origem } & Esquerda & 3 & 9 & 16 & $28(11,1 \%)$ \\
\hline & Centro & - & 12 & 45 & $57(22,5 \%)$ \\
\hline & Direita & 4 & 18 & 146 & $168(66,4 \%)$ \\
\hline \multirow{2}{*}{\multicolumn{2}{|c|}{ Casos válidos }} & 7 & 39 & 207 & 253 \\
\hline & & $(2,8 \%)$ & $(15,4 \%)$ & $(81,8 \%)$ & (100\%) \\
\hline
\end{tabular}

Fonte de dados brutos: Instituto Datafolha e Cesop/Unicamp - Banco de dados. Elaboração do autor.

Tabela A2

Coesão Média dos Deputados Identificados nas Pesquisas de Opinião, por Partido Político, Segundo a Categoria de Fidelidade

Câmara dos Deputados (1991-1996)

\begin{tabular}{l|c|c|c|c|c|c}
\hline \multirow{2}{*}{ Partidos Políticos } & \multicolumn{6}{|c}{ Coesão Média dos Deputados } \\
\cline { 2 - 7 } & \multicolumn{2}{|c}{ Migrantes } & \multicolumn{2}{c}{ Não-Migrantes } & Total & Casos \\
\hline PDS/PPB & 75,9 & $(56)$ & 74,7 & $(177)$ & 75 & $(233)$ \\
PFL & 74 & $(31)$ & 75,2 & $(279)$ & 75,1 & $(310)$ \\
PSDB & 73 & $(8)$ & 78,1 & $(190)$ & 77,9 & $(198)$ \\
PTB & 68,5 & $(24)$ & 72,3 & $(101)$ & 71,6 & $(125)$ \\
PMDB & 71,7 & $(43)$ & 74,1 & $(384)$ & 73,9 & $(427)$ \\
PDT & 73,4 & $(23)$ & 70,6 & $(132)$ & 71 & $(155)$ \\
PT & 99 & $(1)$ & 78,6 & $(185)$ & 78,7 & $(186)$ \\
PPE & 69,3 & $(7)$ & 85,1 & $(76)$ & 83,7 & $(83)$ \\
PPD & 74,9 & $(72)$ & 76,1 & $(156)$ & 75,7 & $(228)$ \\
\hline
\end{tabular}

Fonte de dados brutos: Instituto Datafolha e Cesop/Unicamp - Banco de dados. Elaboração do autor.

Obs.: PPE reúne os pequenos partidos de esquerda; PPD, os pequenos de direita. Número de casos entre parênteses. 
Tabela A3

Número e Porcentagem de Deputados, por Legislatura,

Segundo a Categoria de Fidelidade

Câmara dos Deputados (1991-2004)

\begin{tabular}{|c|c|c|c|c|c|c|c|c|c|c|}
\hline \multirow{2}{*}{$\begin{array}{l}\text { Categoria } \\
\text { de Fidelidade }\end{array}$} & \multicolumn{2}{|c|}{$\begin{array}{c}48^{\mathrm{a}} \\
\text { Legislatura }\end{array}$} & \multicolumn{2}{|c|}{$\begin{array}{c}49^{\mathrm{a}} \\
\text { Legislatura }\end{array}$} & \multicolumn{2}{|c|}{$\begin{array}{c}50^{-} \\
\text {Legislatura }\end{array}$} & \multicolumn{2}{|c|}{$\begin{array}{c}51^{\mathrm{a}} \\
\text { Legislatura }\end{array}$} & \multicolumn{2}{|c|}{$\begin{array}{c}52^{\mathrm{a}} \\
\text { Legislatura }\end{array}$} \\
\hline & $\mathbf{n}$ & $\%$ & $\mathbf{n}$ & $\%$ & $\mathbf{n}$ & $\%$ & $\mathbf{n}$ & $\%$ & $\mathbf{n}$ & $\%$ \\
\hline Leais & 363 & 61,8 & 431 & 69,5 & 466 & 73,4 & 473 & 73,5 & 454 & 77,4 \\
\hline Desertores & 224 & 38,2 & 189 & 30,5 & 169 & 26,6 & 171 & 26,5 & 132 & 22,6 \\
\hline Total & 587 & 100 & 620 & 100 & 635 & 100 & 644 & 100 & 586 & 100 \\
\hline
\end{tabular}

Fonte de dados brutos: Cebrap - Banco de dados Votação Nominal da Câmara dos Deputados. Elaboração do autor.

Obs.: O número de deputados que compõem a Câmara é de 487 na $48^{\underline{a}}$ legislatura; 503, na 49ª̈; e 513, nas demais. Os dados da 52ª legislatura abrangem a movimentação partidária registrada até o dia 24 de janeiro de 2005. Nessa contagem, incluíram-se os deputados que assumiram o mandato em algum momento da legislatura e votaram pelo menos 10 vezes. No caso dos migrantes, o critério de inclusão é ter votado 10 vezes no partido de origem e de destino. Na $48^{\underline{a}}$ legislatura, não contei a saída dos deputados do PMDB para fundar o PSDB. A fusão do PDS, PDC, PPR e PP foi desconsiderada, assim como a união do PTR e do PST junto ao PP, em 1993.

Tabela A4

Contagem Múltipla de Deputados, por Partido Político,

Segundo a sua Categoria de Fidelidade

Câmara dos Deputados (1991-2004)

\begin{tabular}{|c|c|c|c|c|c|c|c|c|c|c|}
\hline \multirow[t]{2}{*}{$\begin{array}{l}\text { Partidos } \\
\text { Políticos }\end{array}$} & \multicolumn{2}{|c|}{$\begin{array}{c}48^{\mathrm{a}} \\
\text { Legislatura }\end{array}$} & \multicolumn{2}{|c|}{$\begin{array}{c}49^{\mathrm{a}} \\
\text { Legislatura }\end{array}$} & \multicolumn{2}{|c|}{$\begin{array}{c}50^{\mathrm{a}} \\
\text { Legislatura }\end{array}$} & \multicolumn{2}{|c|}{$\begin{array}{c}51^{\mathrm{a}} \\
\text { Legislatura }\end{array}$} & \multicolumn{2}{|c|}{$\begin{array}{c}52^{\mathrm{a}} \\
\text { Legislatura }\end{array}$} \\
\hline & Leais & $\begin{array}{c}\text { Deser- } \\
\text { tores }\end{array}$ & Leais & $\begin{array}{c}\text { Deser- } \\
\text { tores }\end{array}$ & Leais & $\begin{array}{c}\text { Deser- } \\
\text { tores }\end{array}$ & Leais & $\begin{array}{c}\text { Deser- } \\
\text { tores }\end{array}$ & Leais & $\begin{array}{c}\text { Deser- } \\
\text { tores }\end{array}$ \\
\hline $\mathrm{PDS}>\mathrm{PP}$ & 33 & 25 & 19 & 114 & 67 & 133 & 44 & 51 & 30 & 60 \\
\hline PFL & 105 & 51 & 92 & 55 & 115 & 61 & 112 & 57 & 75 & 22 \\
\hline PSDB & 63 & 12 & 49 & 9 & 107 & 49 & 105 & 46 & 60 & 16 \\
\hline PMDB & 186 & 97 & 127 & 50 & 127 & 55 & 98 & 41 & 70 & 16 \\
\hline PTB & 25 & 11 & 28 & 32 & 30 & 32 & 31 & 11 & 39 & 15 \\
\hline PDT & 44 & 15 & 39 & 24 & 27 & 24 & 21 & 11 & 14 & 5 \\
\hline PT & 20 & 2 & 37 & 3 & 56 & - & 74 & 4 & 93 & 5 \\
\hline PPE & 14 & 3 & 17 & 15 & 26 & 5 & 39 & 7 & 56 & 19 \\
\hline PPD & 50 & 55 & 27 & 126 & 12 & 22 & 16 & 29 & 40 & 10 \\
\hline
\end{tabular}

Fonte de dados brutos: Cebrap - Banco de dados Votação Nominal da Câmara dos Deputados. Elaboração do autor.

Obs.: Essa contagem inclui as mudanças múltiplas de filiação, de modo a contemplar toda movimentação registrada entre os partidos. A sigla PPE agrega os pequenos partidos de esquerda; a sigla PPD, os pequenos de direita. 
Os Efeitos da Migração Interpartidária na Conduta Parlamentar

Tabela A5

Distância Média Percorrida pelos Deputados Migrantes, por Partido Político de Origem e Destino

Câmara dos Deputados (1991-2004)

\begin{tabular}{l|c|c|c|c|c|c|c|c|c}
\hline \multirow{2}{*}{ Origem } & \multicolumn{7}{|c}{ Destino } \\
\cline { 2 - 9 } & PDS>PP & PFL & PSDB & PMDB & PTB & PDT & PT & PPE & PPD \\
\hline PDS>PP & & & & & & & & & \\
PFL & 37 & & & & & & & & \\
PSDB & 18 & 16 & & & & & & & \\
PMDB & 15 & 16 & 30 & & & & & & \\
PTB & 9 & 15 & 13 & 11 & & & & & \\
PDT & 3 & 1 & 10 & 3 & 2 & & & & \\
PT & - & & 1 & - & & - & & & \\
PPE & 4 & 2 & 8 & 17 & 2 & 8 & 4 & 3 & \\
PPD & 47 & 35 & 13 & 11 & 11 & 4 & - & 4 & 29 \\
\hline
\end{tabular}

Fonte de dados: Cebrap - Banco de dados Votação Nominal da Câmara dos Deputados. Elaboração do autor.

\section{Gráfico A1}

Posições que os Partidos Ocupam no Espectro Ideológico Câmara dos Deputados (1991-2004)

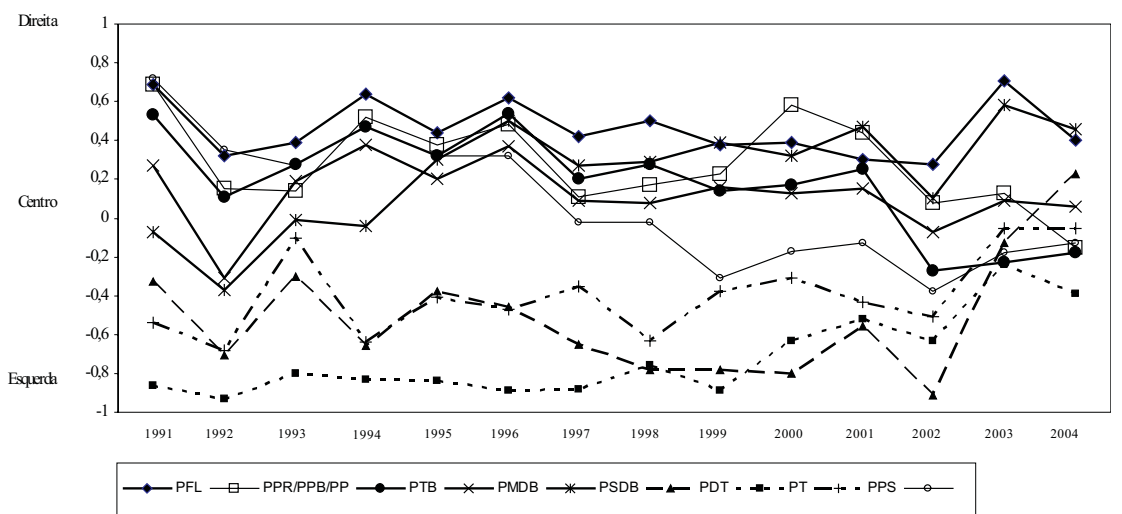


Celso Roma

\section{Gráfico A2}

Posições que os Partidos Ocuparam no Espectro Ideológico

Câmara dos Representantes - Estados Unidos (1879-2003)

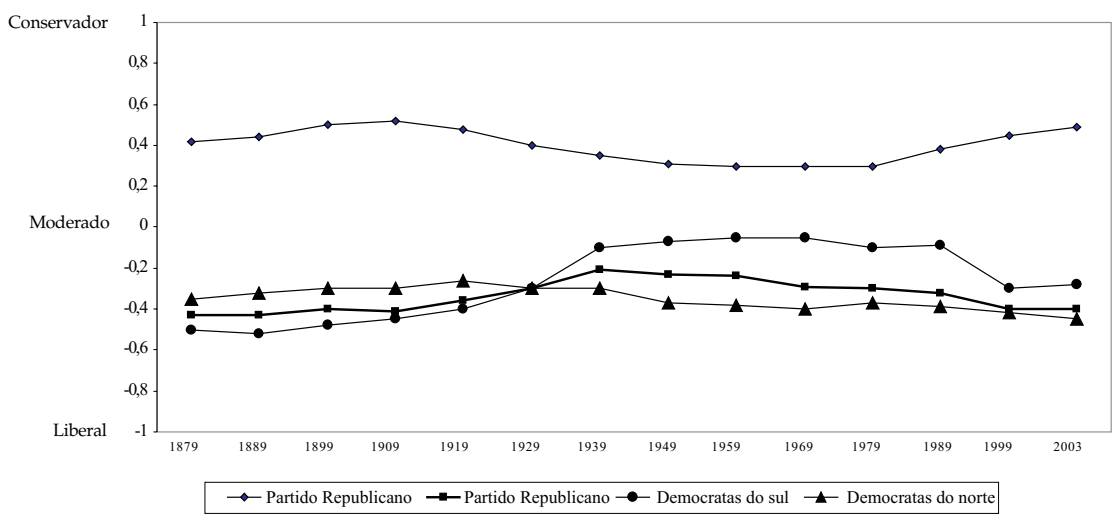

Fonte: Adaptação de Voteview - Banco de dados Roll-call Voting in House of Representatives. Elaboração do autor. 


\section{Lista de Siglas}

PC do B - Partido Comunista do Brasil

PDC - Partido Democrata Cristão

PDS - Partido Democrático Social

PDT - Partido Democrático Trabalhista

PFL - Partido da Frente Liberal

PL - Partido Liberal

PMDB - Partido do Movimento Democrático Brasileiro

PMN - Partido da Mobilização Nacional

PP - Partido Progressista

PPB - Partido Progressista Brasileiro

PPR - Partido Progressista Reformador

PPS - Partido Popular Socialista

PRN - Partido da Reconstrução Nacional

Prona - Partido de Reedificação da Ordem Nacional

PRP - Partido Republicano Progressista

PRT - Partido Reformador Trabalhista

PSB - Partido Socialista Brasileiro

PSC - Partido Social Cristão

PSD - Partido Social Democrático

PSDB - Partido da Social Democracia Brasileira

PSL - Partido Social Liberal

PST - Partido Social Trabalhista

PT - Partido dos Trabalhadores

PTB - Partido Trabalhista Brasileiro

PTR - Partido Reformador Trabalhista

PV - Partido Verde 


\section{Celso Roma}

\section{ABSTRACT}

The Effects of Inter-Party Migration on Congressional Conduct

The objectives of this article were to compare the performance of members of Congress who remain loyal to their original party versus those who desert, in terms of party cohesion and discipline, as well as to measure the effects of changing parties on the migrants' conduct and ideas. The study uses data from records on party changes, roll call votes, and opinion polls. Based on these data, regardless of whether members of Congress had switched parties or not, they showed a high degree of partisanship. In addition, most party deserters adhered to the ideas and voting patterns of their new party. Compared to the Brazilian case, political party migration in the United States differs as to frequency, motives, and impact.

Key words: migration; political party; Chamber of Deputies

\section{RÉSUMÉ \\ Les Effets de la Migration d'un Parti à l'Autre dans l'Exercice Parlementaire}

Dans cet article, on cherche à comparer les performances des députés loyaux et déserteurs sous l'angle de la cohésion et de la discipline de parti, ainsi qu'à mesurer les effets du changement de parti sur la conduite et sur la façon de penser des migrants. Les données exploitées englobent des fiches de changements de parti, des élections nominales et des enquêtes d'opinion. Selon l'analyse de ces données, les députés, fidèles ou non, montrent un haut degré d'adhésion au système des partis. Par ailleurs, la plupart des déserteurs reproduit, dans le parti où ils atterrissent, leur façon de penser et de voter. Si on la compare au cas brésilien, la migration d'un parti à l'autre aux États-Unis est assez différente par sa fréquence, ses raisons et son impact

Mots-clé: migration; parti politique; Chambre des Députés 